\title{
FOSSIL PROBOSCIDEA FROM THE UPPER CENOZOIC OF CENTRAL AMERICA: TAXONOMY, EVOLUTIONARY AND PALEOBIOGEOGRAPHIC SIGNIFICANCE
}

\author{
PROBOSCIDEOS FÓSILES DEL CENOZOICO SUPERIOR DE \\ AMÉRICA CENTRAL: TAXONOMÍA, EVOLUCIÓNY SIGNIFICADO PALEOGEOGRÁFICO
}

\author{
Spencer G. Lucas ${ }^{*}$ \& Guillermo E. Alvarado ${ }^{2}$ \\ ${ }^{1}$ New Mexico Museum of Natural History and Science, 1801 Mountain Road \\ N.W., Albuquerque, New Mexico 87104 USA \\ ${ }^{2}$ Escuela Centroamericana de Geología, Universidad de Costa Rica, \\ Apdo. 214, 2060, San José, Costa Rica \\ *Autor para contacto: spencer.lucas@state.nm.us
}

(Recibido: 03/02/2010; aceptado: 22/06/2010)

\begin{abstract}
Fossils of proboscideans from Central America are assigned to four genera: Gomphotherium, Cuvieronius, Mammut and Mammuthus. Previous reports of Stegomastodon, Rhynchotherium and Haplomastodon from Central America are based on incorrect taxonomic identifications or on fossils not definitely diagnostic of these genera. The oldest proboscidean records from Central America (Guatemala, El Salvador, Honduras, and Costa Rica) are Late Miocene (early Hemphillian, $7 \mathrm{Ma}$ ) records of Gomphotherium, and this suggests that gomphotheres dispersed from North America to Central America about nine million years after they dispersed from Asia to North America. However, there is no conclusive evidence that they dispersed into South America, where there are no records of Gomphotherium, so the Miocene Panamanian seaway apparently was a barrier to proboscidean dispersal. During the Late Pliocene, Cuvieronius arose from a gomphothere ancestor in North America ( $3 \mathrm{Ma}$ ) and during the Late Pliocene (late Blancan) dispersed southward through Central America to South America. Mammuthus is known from two species in Central America, an Early Pleistocene species (M. meridionalis) and a more common Late Pleistocene species (M. columbi). Mammut has a single Central American record (Honduras), which is probably of Late Pleistocene age. Neither Mammuthus nor Mammut have records in South America. Central America was not a center of evolution of proboscideans during the late Cenozoic, instead, it was a pathway across which the Proboscidea migrated. There was a single immigration of Cuvieronius from Central America to South America during the Late Pliocene ( 2.5 Ma). All South American proboscideans are Plio-Pleistocene Cuvieronius, or its descendants Notiomastodon and Haplomastodon.

Keywords: Proboscidea, Central America, Gomphotherium, Cuvieronius, Rhynchotherium, Haplomastodon, Stegomastodon, Notiomastodon, Mammuthus, Mammut.
\end{abstract}




\begin{abstract}
RESUMEN: Los fósiles de proboscideos de América Central se asignan a cuatro géneros: Gomphotherium, Cuvieronius, Mammut y Mammuthus. Los trabajos previos de Stegomastodon, Rhynchotherium y Haplomastodon para la región se basaron en identificaciones taxonómicas desactualizadas o en fósiles no diagnósticos para estos géneros. El proboscidio más antiguo para Centroamérica (Guatemala, El Salvador, Honduras y Costa Rica) es el registro de Gomphotherium del Mioceno (Hemphiliano, $\sim 7 \mathrm{Ma}$ ), sugiriendo que los gonfoterios se dispersaron desde Norteamérica a Centroamérica aproximadamente hace 9 millones de años después de que ellos se dispersaran desde Asia a Norteamérica. Sin embargo, no existe evidencia de que se dispersaran a Sudamérica, donde no existen registros de Gomphotherium, así que el canal interoceánico panameño del Mioceno debió de haber representado una barrera para su dispersión. Durante el Plioceno Tardío, el Cuvieronius evolucionó de un ancestro del Gomphotherium norteamericano y subsecuentemente se dispersó hacia el sur a través de América Central a Sudamérica (Plioceno Tardío). El Mammut posee un único registro en América Central (Honduras), posiblemente del Pleistoceno Tardío. Se conoce dos especies de Mammuthus, una del Pleistoceno Temprano (M. meridionalis) y una más abundante del Pleistoceno Tardío (M. columbi). Significativamente, ni el Mammut o el Mammuthus poseen registros en Sudamérica. América Central no funcionó como un centro de evolución u origen de algún nuevo taxón de proboscidio durante el Cenozoico Tardío, pese a ello, si fue un lugar de paso o tránsito migratorio. El Gomphotherium arribó a Centroamérica durante el Mioceno Tardío, el Cuvieronius durante el Plioceno Tardío, Mammuthus durante el Pleistoceno Temprano y el Mammut hasta el Pleistoceno Tardío. Existió una única emigración de Cuvieronius desde América Central a Sudamérica durante el Plioceno Tardío ( 2,5 Ma). Todos los proboscídeos sudamericanos son Cuvieronius, o sus descendientes directos Notiomastodon y Haplomastodon durante el Plio-Pleistoceno.

Palabras clave: Proboscidea, América Central, Gomphotherium, Cuvieronius, Rhynchotherium, Haplomastodon, Stegomastodon, Notiomastodon, Mammuthus, Mammut.
\end{abstract}

\section{INTRODUCTION}

Proboscidea is an order of mammals popularly referred to as elephants and their allies. Proboscideans originated in Africa during the Paleocene (Gheerbrant, 2009). They subsequently spread to Eurasia during the Early Miocene after Africa docked with Eurasia via the Arabian Peninsula (Shoshani et al., 1996; Tassy, 1996). By middle Miocene time, about $16 \mathrm{Ma}$, proboscideans crossed Beringia into North America and spread rapidly through the continent (Tedford et al., 2004; Prothero et al., 2008). Proboscideans first appeared in Central America during the Late Miocene, about $7 \mathrm{Ma}$, and they persisted there until their extinction at about the end of the Pleistocene. During the Pliocene, soon after the closure of the Panamanian isthmus, proboscideans continued to spread southward, into South America as far south as Chile and Argentina.

Central America has a diverse and complex fossil record of proboscideans of MiocenePleistocene age. By our count, there are at least 74 localities in Central America that have yielded proboscidean fossils, about 43 of which are well documented (Fig. 1; Table 1; Appendix). Here, we present a critical review of the Central American record of proboscideans, based in part on recent taxonomic revisions and on more than two decades of research on their fossil record. These taxonomic revisions are the primary reason for fundamental differences between our review of the Central American proboscidean record and that of Arroyo-Cabrales et al. (2007), who used a different approach to the taxonomy and apparently did not review some of the records listed here.

We evaluate also the evolutionary and paleobiogeographic significance of these records to conclude that Central America was an important pathway to a single immigration of proboscideans from North to South America. In this article, LMA = land-mammal "age," $\mathrm{m}=$ lower molar and $\mathrm{M}=$ upper molar. We emphasize that in several cases, particularly with incomplete and juvenile proboscidean specimens, the taxonomic classification is not easy and several genera have overlapping diagnostic criteria, particularly in their juvenile molars (i.e., Gomphotherium, Rhynchotherium, Cuvieronius, Haplomastodon). The ideal specimen for a certain identification is either a complete skull, lower jaw and/or tusks, but in a tropical area with heavy rainfall conditions such as Central America, such ideal preservation is rare. 


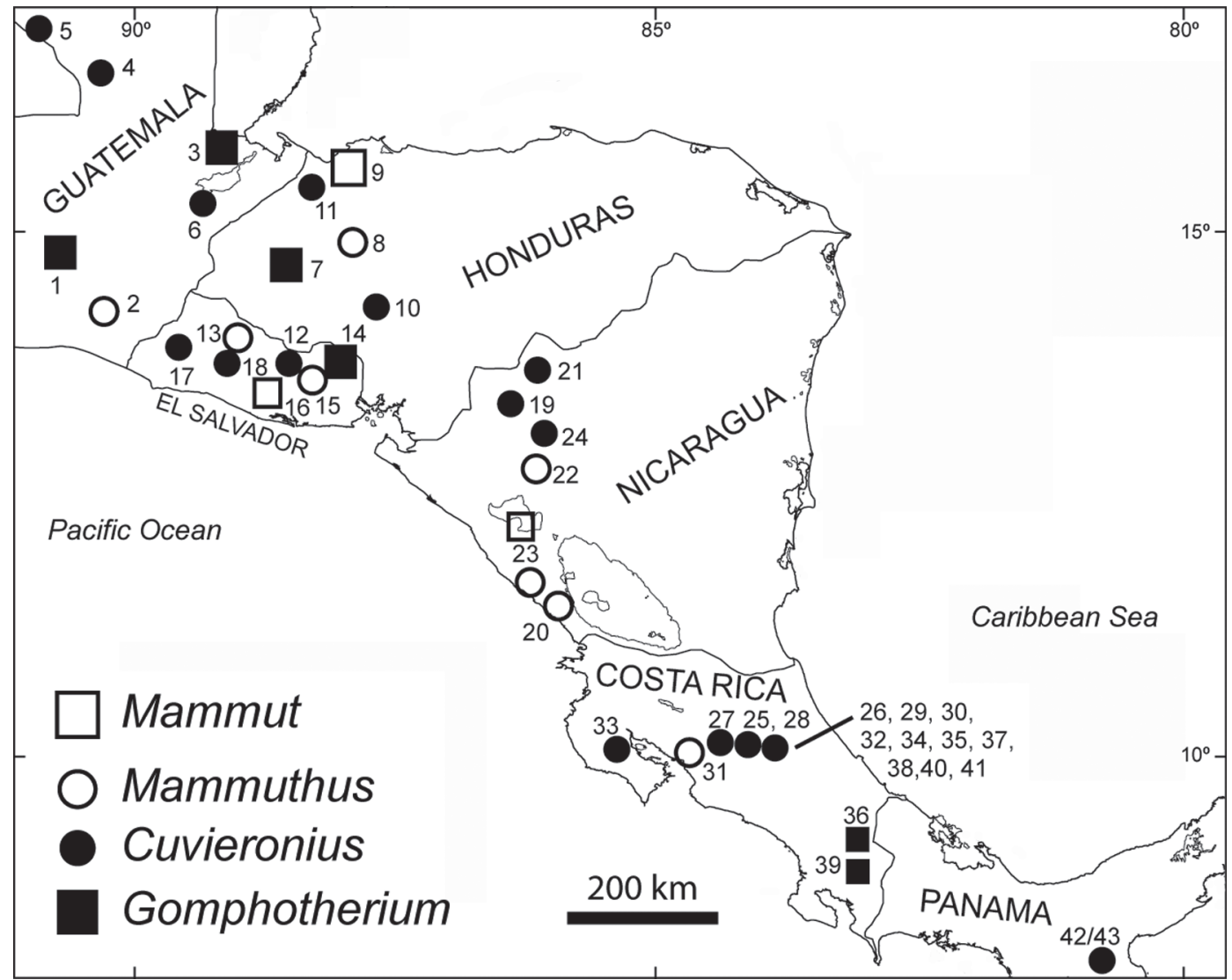

Fig. 1: Central American proboscidean localities. See Table 1 for locality list that matches numbers on the figure

\section{GEOLOGICAL TIMESCALE}

Ages were assigned to proboscidean fossils from Central America based primarily on the North American LMAs, characterized and correlated to the late Cenozoic epochs by Tedford et al. (2004) for the Miocene and by Bell et al. (2004) for the Pliocene-Recent. We thus use the traditional definition of the base of the Pleistocene at about $1.8 \mathrm{Ma}$, instead of the newly proposed definition, which lowers the Pleistocene base to about 2.6 Ma. Thus, the LMAs relevant to the Central American proboscidean record are: (1) Hemphillian: Late Miocene-Early Pliocene, 4.7-9.0 Ma; (2) Blancan: Early Pliocene-Early Pleistocene, $\sim 1.8-4.7 \mathrm{Ma}$; (3) Irvingtonian:
Early-Middle Pleistocene, 200,000 years-1.8 $\mathrm{Ma}$; and (4) Rancholabrean: Late Pleistocene, $\sim$ 10,000-200,000 years. We also discuss the Marplatan South American LMA here, and based on Woodburne et al. (2006; also see Requero et al., 2007) its age is $~ 1.9-3.2 \mathrm{Ma}$.

\section{CENTRAL AMERICAN PROBOSCIDEAN TAXONOMY}

We recognize four genera of fossil proboscideans from Central America: Gomphotherium, Cuvieronius, Mammut and Mammuthus. Other workers (including ourselves, and most recently Arroyo-Cabrales et al., 2007) have previously identified three other proboscidean 
Table 1

List of the well documented proboscidean localities in Central America (see Fig.1 and the Appendix)

\begin{tabular}{|c|c|c|c|}
\hline Number (Fig.1) & Locality & Age & Proboscidean \\
\hline \multicolumn{4}{|l|}{ Guatemala } \\
\hline 1 & Chinautla & Hemphillian? & Gomphotherium \\
\hline 2 & Estanzuela & Pleistocene & Mammuthus \\
\hline 3 & Río Carboneras & Hemphillian? & Gomphotherium \\
\hline 4 & Río de la Pasión & Rancholabrean & Cuvieronius \\
\hline 5 & Río Usmancita & Pleistocene? & Cuvieronius \\
\hline 6 & Zacapa & Pleistocene? & Cuvieronius \\
\hline \multicolumn{4}{|l|}{ Honduras } \\
\hline 7 & Gracias & Hemphillian & Gomphotherium \\
\hline 8 & Orillas de Humaya & Rancholabrean & Mammuthus \\
\hline 9 & San Pedro Sula & Pleistocene? & Mammut \\
\hline 10 & Tambla (Humuya) & Pleistocene? & Cuvieronius \\
\hline 11 & Yeroconte & Rancholabrean & Cuvieronius? \\
\hline \multicolumn{4}{|l|}{ EI Salvador } \\
\hline 12 & Barranca del Sisimico & Irvingtonian & Cuvieronius \\
\hline 13 & Chaltenango & Irvingtonian & Cuvieronius/Mammuthus \\
\hline 14 & Corinto & Hemphillian & Gomphotherium \\
\hline 15 & El Hormiguero & Rancholabrean & Mammuthus \\
\hline 16 & Río de Jerusalén & Pleistocene & Mammuthus \\
\hline 17 & Santa Ana & Pleistocene & Cuvieronius \\
\hline 18 & Tomayate & Irvingtonian & Cuvieronius \\
\hline \multicolumn{4}{|l|}{ Nicaragua } \\
\hline 19 & El Bosque & Rancholabrean & Cuvieronius \\
\hline 20 & El Palmar & Pleistocene & Mammuthus \\
\hline 21 & Jalapa & Rancholabrean & Cuvieronius \\
\hline 22 & Las Banderas & Pleistocene & Mammuthus \\
\hline 23 & Masachapa & Pleistocene & Mammuthus \\
\hline 24 & Matagalpa & Pleistocene? & Cuvieronius \\
\hline \multicolumn{4}{|l|}{ Costa Rica } \\
\hline 25 & Agua Caliente & Late Pleistocene & Cuvieronius \\
\hline 26 & Bajo Barrantes & $\begin{array}{l}\text { Late Pliocene-Early Pleis- } \\
\text { tocene? }\end{array}$ & Cuvieronius \\
\hline 27 & Buenos Aires de Palmares & Middle Pleistocene & Cuvieronius \\
\hline 28 & Cachí & Pleistocene? & Cuvieronius \\
\hline 29 & Candelaria & Pleistocene? & Cuvieronius \\
\hline 30 & Claras de Guayabo de Mora & Pleistocene? & Cuvieronius \\
\hline 31 & Hacienda del Silencio & Pleistocene & Mammuthus \\
\hline 32 & Paseo Colón & Late Pleistocene & Cuvieronius \\
\hline
\end{tabular}


Table 1 (continuation)

\begin{tabular}{cccc}
\hline Number (Fig. 1) & Locality & Age & Proboscidean \\
\hline 33 & Península de Nicoya & Pleistocene? & Cuvieronius \\
34 & Quebrada Rivera (Tibás 3) & Late Pleistocene & Cuvieronius \\
35 & Río María Aguilar & Late Pleistocene & Cuvieronius \\
36 & San Gerardo de Limoncito & $\begin{array}{c}\text { Middle-Late Miocene } \\
\text { (Late Miocene?) }\end{array}$ & Gomphotherium \\
37 & Santa Ana & Middle Pleistocene & Cuvieronius \\
38 & Santa Domingo & Middle or Late Pleistocene & Cuvieronius \\
39 & Santa Rita & Middle-Late Miocene & Gomphotherium \\
40 & Tibás 1 & (Late Miocene?) & Cuvieronius \\
41 & Tibás 2 & Late Pleistocene & Cuvieronius \\
\hline Panama & Late Pleistocene & Cuvieronius \\
43 & El Hatillo & Rancholabrean & Cuvieronius \\
\hline
\end{tabular}

genera from Central America---Rhynchotherium, Stegomastodon and Haplomastodon---but, based on revised taxonomy, there are no demonstrable records of these proboscidean genera in Central America (below, we briefly review this revised taxonomy).

\section{Gomphotherium}

Gomphotherium (Fig. 2) is an Old World and New World gomphothere with a long stratigraphic range through most of the Miocene and Pliocene. One of the first proboscideans to reach the New World, Gomphotherium is considered to have been ancestral to the more derived New World gomphotheres Stegomastodon, Rhynchotherium and Cuvieronius (e.g., Tobien, 1973; Lambert \& Shoshani, 1998). Gomphotherium is characterized by its low and long skull with upper tusks with enamel bands, lower jaw with two elongate lower tusks in an elongate mandibular symphysis and last molars with 3-5 lophs/lophids that wear to single trefoils (e.g., Tobien, 1973; Lambert \& Shoshani, 1998).

Gomphotherium was common in North America during the Miocene (Barstovian-early Hemphillian), but rare during the Pliocene (late
Hemphillian). Its records in North America extend as far south as southern Mexico (e.g., Ferrusquia-Villafranca, 1984, 1990; Lambert \& Shoshani, 1998). A large number of species of Gomphotherium have been recognized, but Tobien (1978) argued that only one North American species is valid, G. productum. However, we believe the genus is more speciose in the New World (cf. Heckert et al., 2000) and that there are at least two species known from North America, and another is known from Central America. Thus, we accept the conclusion of Lucas \& Morgan (2008) that the Central American species Gomphotherium hondurensis $(=$ Aybelodon hondurensis, $=$ Blickotherium blicki) (Fig. 3) is not a species of Rhynchotherium, but instead a derived species of Gomphotherium.

\section{Cuvieronius}

Cuvieronius (Fig. 2) is a New World gomphothere known from the Pliocene-Pleistocene of North America and the Pleistocene of Central and South America (e.g., Dudley, 1996; Lambert, 1996; Lambert \& Shoshani, 1998; Prado et al., 2005; Lucas, 2008a; Ferretti, 2008). Cuvieronius is generally considered closely related to or derived 

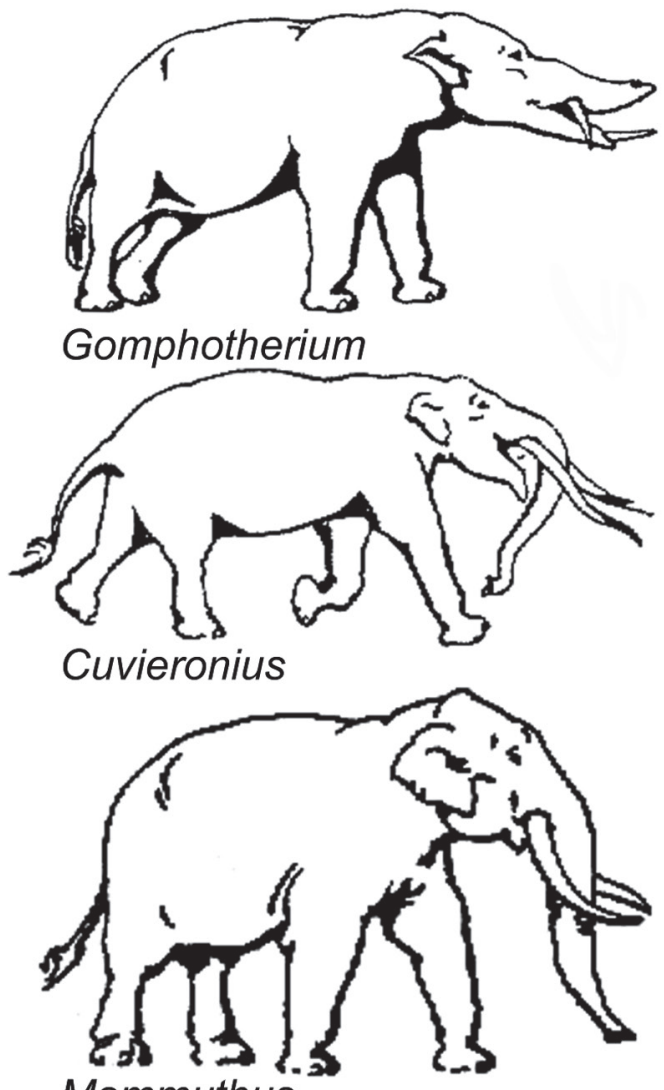

\section{Mammuthus}

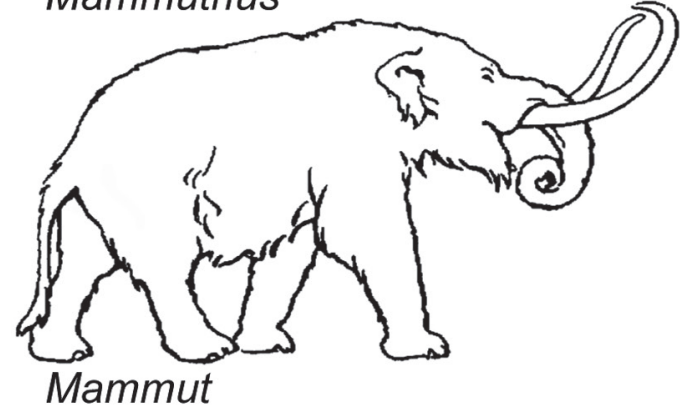

Fig. 2: Outline restorations of the four genera of Central American proboscideans; not to scale (after Osborn, 1936)

from the Pliocene gomphothere Rhynchotherium in North America and to have spread to Central and South America during the Pliocene (e.g., Tobien, 1973; Kurtén \& Anderson, 1980; Webb \& Perrigo, 1984; Miller, 1990; Dudley, 1996). In
North America, Cuvieronius records are known across Mexico (e.g., Montellano-Ballesteros, 2002; Alberdi \& Corona-M., 2005) and in the southern United States in Arizona, New Mexico, Texas and Florida (e.g., Kurtén \& Anderson, 1980; Dalquest \& Schultz, 1992; Webb \& Dudley, 1995; Lucas et al., 1999, 2000; Hulbert, 2001; Vance, 2002; Bell et al., 2004; Lucas \& Morgan, 2005; Lucas, 2008a).

Characteristic features of Cuvieronius include its relatively long and low vaulted skull, large upper tusks with spiral enamel bands, lack of lower tusks, short mandibular symphysis that is not strongly downturned and bunolophodont third molars that have 4-5 lophs/lophids with slightly alternating cusps between them (Fig. 4). The twisted upper tusk, with its spiral band of enamel, is a derived feature shared by Cuvieronius and Rhynchotherium.

Most recent workers have generally regarded two species of Cuvieronius as valid, the type species C. hyodon (Fischer, 1814) and C. tropicus (Cope, 1884) (cf. Shoshani \& Tassy, 1996). Indeed, it became traditional to refer all North American (from Mexico northward) specimens of Cuvieronius to C. tropicus, and to refer all South American specimens to C. hyodon. Some authors referred Central American (especially specimens from Honduras, Costa Rica and El Salvador) specimens to C. hyodon (e. g. Laurito, 1988) whereas others referred them to C. tropicus (e. g., Webb \& Perrigo, 1984). A few authors remained undecided as to any species-level assignments pending a revision, or simply fell back on using the type species C. hyodon (e.g., Lambert, 1996; Lambert \& Shoshani, 1998; Vance, 2002). However, as Lucas (2008a) concluded, extensive revision of the South American specimens of Cuvieronius (see especially Frassinetti \& Alberdi, 2000; Prado et al., 2002, 2003, 2005; Alberdi et al., 2004) has established a range of variation in molar morphology for $C$. hyodon that encompasses the type specimen of $C$. tropicus.

Thus, Montellano-Ballesteros (2002) discussed the possible distinctiveness of Cuvieronius 


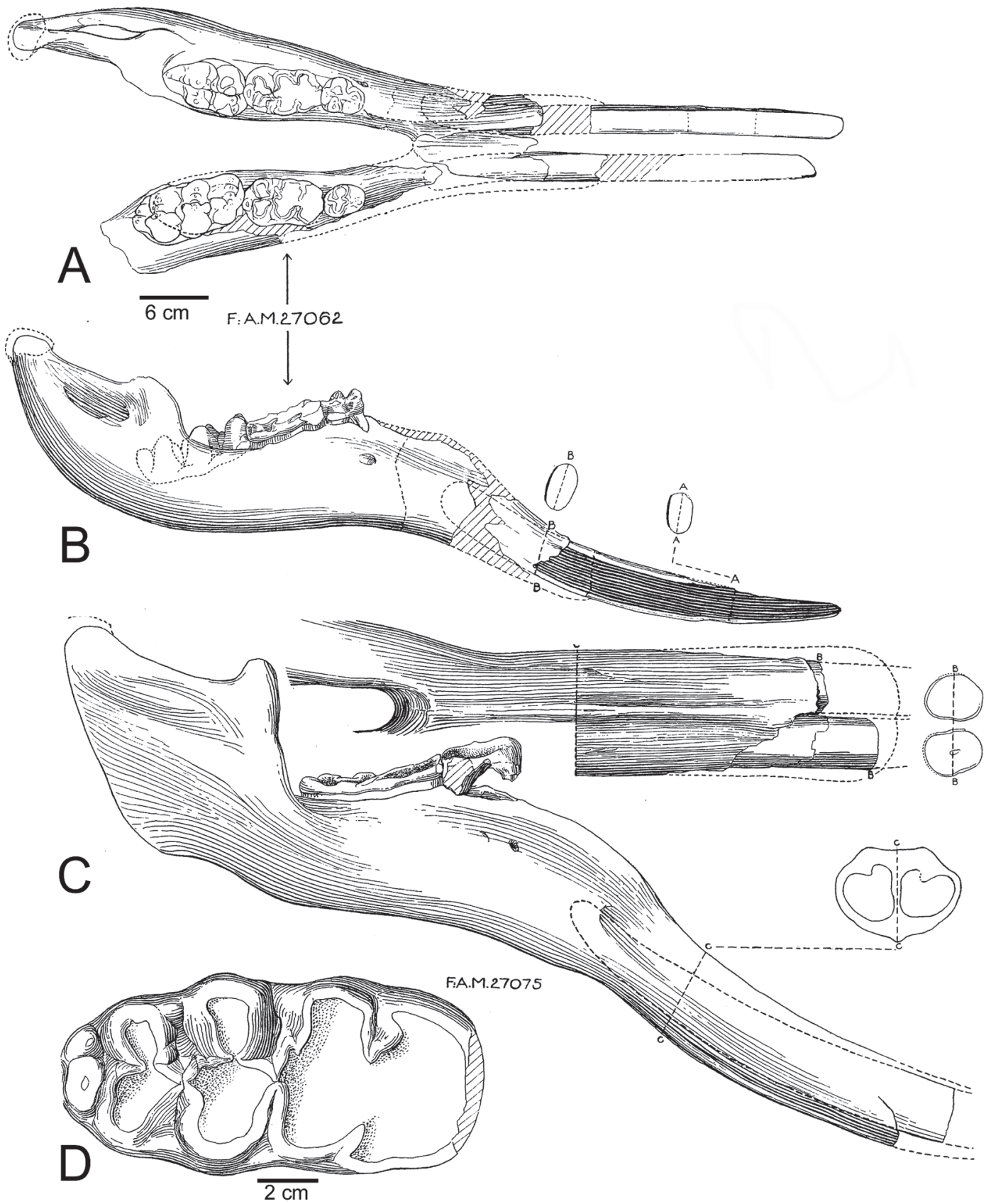

Fig. 3: Selected Gomphotherium hondurensis from the Late Miocene (Hemphillian) of Honduras--holotypes of Blickotherium blicki and Aybelodon hondurensis from the Gracias local fauna. A-B, Holotype of Blickotherium blicki, in occlusal (A) and right lateral (B) views. C-D, Holotype of Aybelodon hondurensis, lower jaw in ventral and lateral views (C) and right $\mathrm{m} 3$ in occlusal view (D). Modified from Frick (1933, figs. 4-5). One scale bar for A-C, separate scale bar for D 


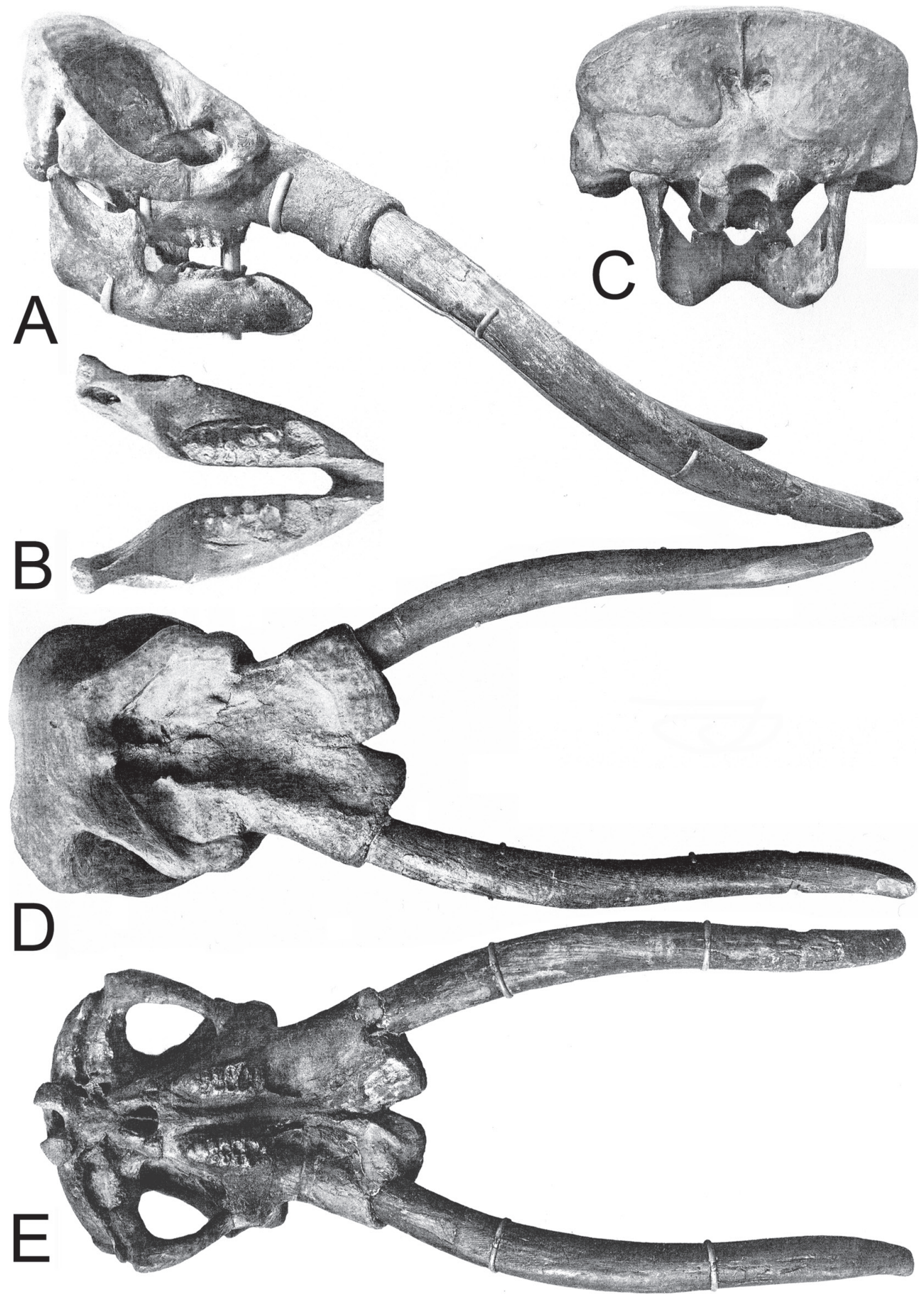

Fig. 4: Characteristic skull and lower jaw of Cuvieronius hyodon. MNHN (Musée Nationale d'Histoire Naturelle, Paris) TAR 1270, from Tarija, Bolivia, proposed as neotype of Mastotherium hyodon Fischer, 1814 by Lucas (2009b). A, Right lateral view of skull and lower jaw. B, Occlusal view of lower jaw. C, Occipital view of skull and lower jaw. D, Dorsal view of skull. E, Ventral view of skull. For scale, maximum length of skull (including tusks) $=210 \mathrm{~cm}$. Modified from Boule \& Thevenin $(1920$, pls. 1-3) 


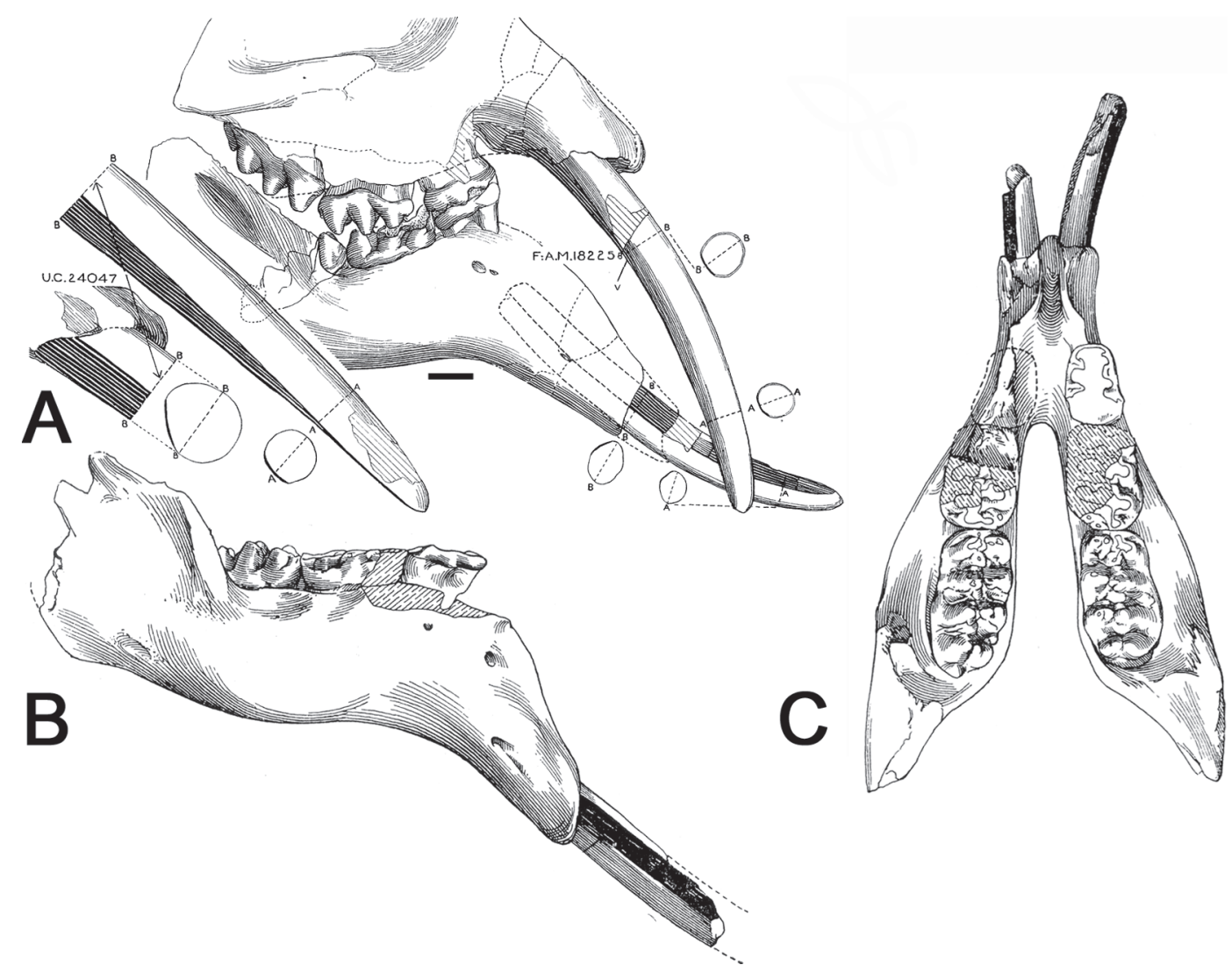

Fig. 5: Skull, tusk, lower jaw and cheek tooth morphology of Rhynchotherium tlascalae. A, Comparison of upper tusk of Rhynchotherium edensis syntype (UCMP [University of California, Museum of Paleontology] 24047) on left, and juvenile skull and lower jaws (F:AM [Frick Collection, American Museum of Natural History] 18225; modified from Frick, 1933, fig.1). B-C, Type lower jaw of Rhynchotherium browni (from Osborn, 1936) in right lateral (B) and occlusal (C) views. For scale, m3 length $=174 \mathrm{~mm}$ in $\mathrm{A}$, and $\mathrm{m} 3$ length $=180 \mathrm{~mm}$ for B-C

tropicus, which was based on a right dentary with m2-3 from Mexico that Cope (1884) named Dibelodon tropicus. Montellano-Ballesteros (2002) noted that the only feature of the type of C. tropicus that may diagnose it from $C$. hyodon is its possession of five lophids on the $\mathrm{m} 3$, although she concluded that the variability of this feature had not been fully established. In part, this is because some authors call a fifth lophid on a Cuvieronius $\mathrm{m} 3$ the talonid, depending on its overall width and height. However, a survey of some of the South American specimens referred to $C$. hyodon reveals five-lophid $\mathrm{m} 3 \mathrm{~s}$ very similar to that of the holotype of C. tropicus (e.g., Nordenskiöld, 1903, pl. 3; Pompeckj, 1905, pl. 3, fig. 1a). The Salvadoran specimens of Cuvieronius that Cisneros (2005, fig. 6) assigned to C. tropicus have 4.5 or 5 lophids. Indeed, Prado et al. (2003, 2005; also see Lambert \& Shoshani, 1998) diagnosed C. hyodon as having "four to four and half or five angular lophs" (Prado et al., 2003, p. 23). The $\mathrm{m} 2$ and $\mathrm{m} 3$ lengths and widths of the type specimen of C. tropicus also fall within the range of metric variation of the South American C. hyodon (see Frassinetti \& Alberdi, 2000; Prado et al., 2002, 2003, 2005; Alberdi et al., 2004 for the molar metrics of South American C. hyodon specimens). It is thus impossible to maintain C. tropicus as a valid species distinct from $C$. hyodon. Therefore, Lucas (2008a) argued that Cuvieronius is monospecific, with $C$. tropicus a junior subjective synonym of $C$. hyodon. We accept the conclusion that 

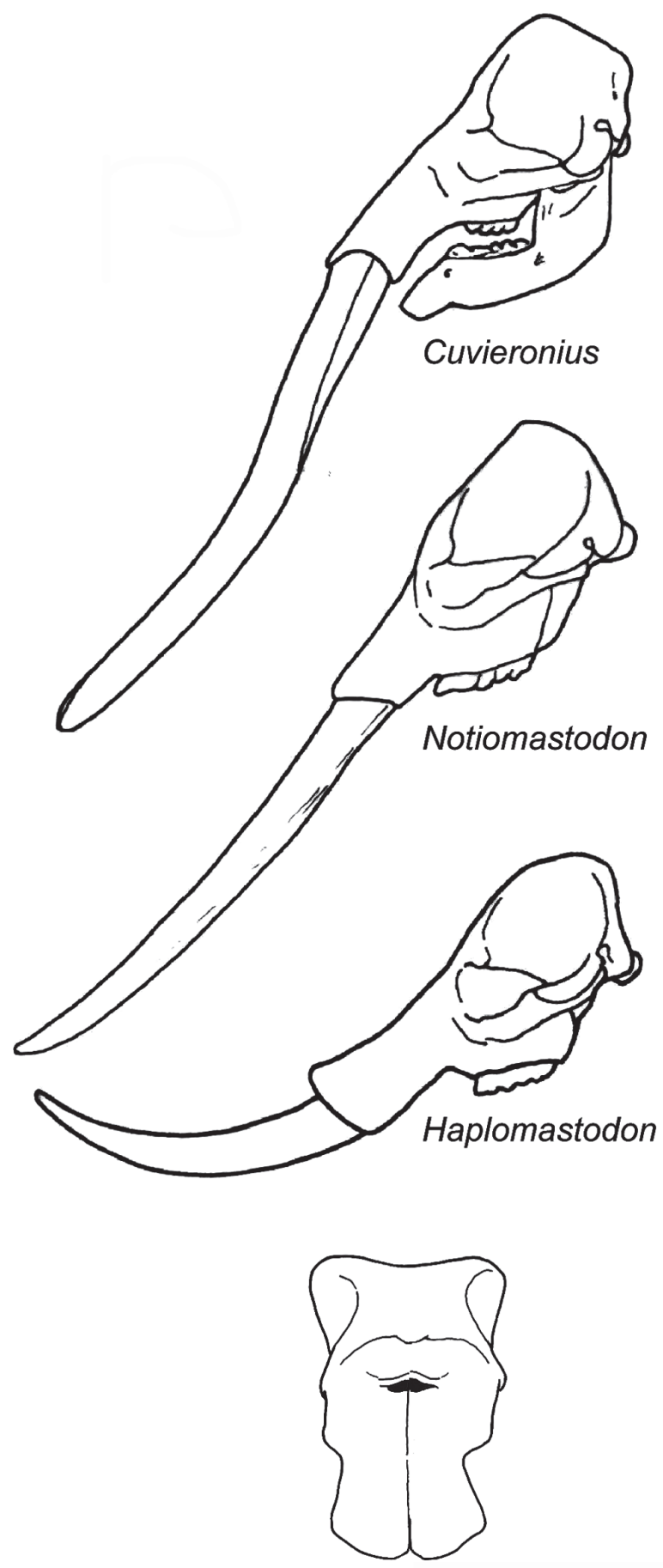

Haplomastodon

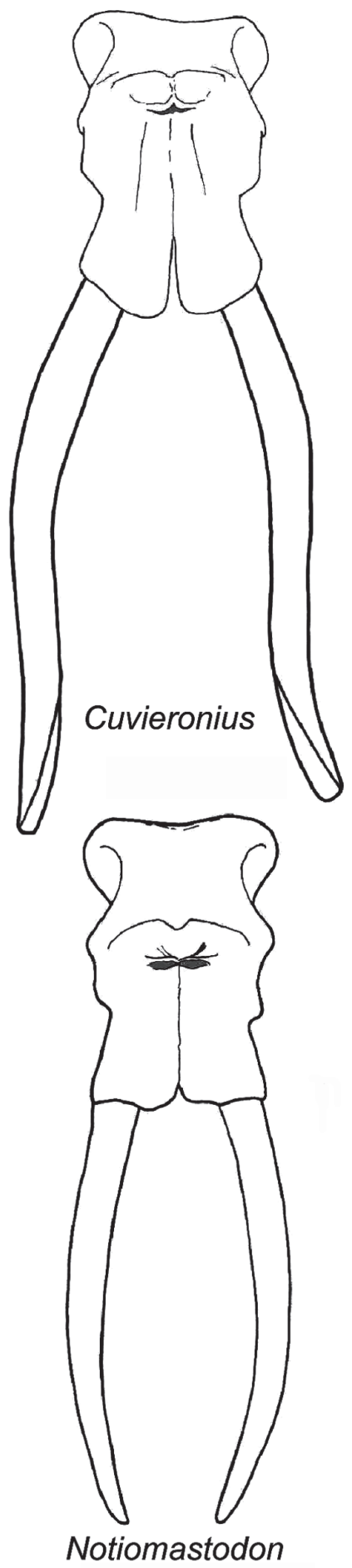

Fig. 6: Skulls of South American gomphotheres: Cuvieronius hyodon, Notiomastodon platensis and Haplomastodon waringi; not to scale. Modified from Ferretti (2008) 
there is one valid species of Cuvieronius (which was also advocated by Laurito, 1988), and refer all Central American specimens of Cuvieronius to C. hyodon, which is the most abundant proboscidean in Central America. Also, the few reported Central American specimens with associated molars, tusks and, in some cases, the lower jaw, are readily assigned to this species (i.e. for example, specimens from Santa Ana and Tibás 2 in Costa Rica: Lucas et al., 1997).

\section{Rhynchotherium}

Rhynchotherium is a genus of advanced gomphotheres known from HemphillianBlancan strata of the New World. It is part of the derived clade of New World gomphotheres that includes Cuvieronius and that is united by the spiral enamel bands on the upper tusks, relatively simple (though variable) cheektooth crown morphology and short lower jaws. Rhynchotherium is diagnosed by its upper tusks with spiral enamel bands, M3/m3 with 4-4.5 relatively simple lophs/lophids, lower jaw with two tusks with flat medial sides and on the lateral sides straight external enamel bands that extend to their tips, a low and blunt coronoid process, deep and thick horizontal ramus below the cheek tooth row, short horizontal symphysis and sharply downturned symphyseal region in which the symphyseal angle is $45^{\circ}$ or more (Fig. 5). This diagnosis indicates that isolated molars and tusk fragments are not diagnostic of Rhynchotherium instead of Cuvieronius, though most Rhynchotherium tend to have less complex and less hypsodont molars than most Cuvieronius. A lower jaw (particularly the symphyseal region) is needed to definitively diagnose specimens of Rhynchotherium from Cuvieronius. Thus, for example, the recent reports of Rhynchotherium from San Gerardo and Santa Rita in Costa Rica based only on upper molars (Laurito \& Valerio, 2005; Valerio \& Laurito, 2008) are of specimens that more likely belong to Gomphotherium and certainly cannot be assigned with confidence to Rhynchotherium (see Lucas \& Morgan, 2008; present paper).
Lucas \& Morgan (2008) presented a comprehensive revision of the taxonomy of Rhynchotherium, and re-assigned the two supposed Rhynchotherium species from Honduras-Blickotherium blicki Frick, 1933 and Aybelodon hondurensis Frick, 1933--to Gomphotherium. Only one species of Rhynchotherium is valid, $R$. tlascalae $(=R$. edense, $=R$. falconeri, $=R$. browni, $=R$. simpsoni), and the isolated tooth records assigned to Rhynchotherium are not diagnostic of the genus (Lucas \& Morgan, 2008). Verified records of $R$. tlascalae thus are from North AmericaMexico, California, Arizona, New Mexico, Texas and Florida. Therefore, there are no confirmed Central American records of Rhynchotherium, and it is unlikely that Rhynchotherium originated in Central America (as some have claimed, such as Webb \& Perrigo, 1984 and Woodburne et al., 2006), and more likely that it originated in North America, given that its entire fossil record is in North America.

\section{Stegomastodon}

Stegomastodon was the last North American gomphothere, with a stratigraphic range of Blancan to Irvingtonian (Lucas et al., 1999, 2000). It has a tall and short skull with large, uniformly curved upper tusks that lack enamel, no lower tusks and molar teeth that wear to a double trefoil.

Kurtén \& Anderson (1980) argued that only a single species of Stegomastodon is valid, S. mirificus (Leidy). However, we believe that a more primitive species is recognizable, which is smaller and has simpler trefoiling. These are Pliocene (Blancan) specimens to which some workers have applied Woodburne's (1961) name $S$. rexroadensis, but the name $S$. primitivus has priority (Lambert \& Shoshani, 1998). Thus, we envision two species of North American Stegomastodon---primitive S. primitivus and the advanced S. mirificus. Stegomastodon records are confined to North America and extend as far south as Jalisco in Mexico (Lucas, 2003; Alberdi \& Corona-M, 2005).

Stegomastodon has been reported from Central America at the El Bosque locality in northern Nicaragua (Espinoza, 1976). However, 
Reshetov (1982) pointed out that this record should be revised, and as Laurito \& Valerio (2005) and Lucas et al. (2008) noted, there has been no documentation of this record. The Late Pleistocene (Rancholabrean LMA) age of the El Bosque fossil assemblage makes it highly unlikely that Stegomastodon was found at the locality. Instead, Cuvieronius is present at the El Bosque locality (Lucas et al., 2008), and it is likely that the report of Stegomastodon was based on misidentification of a cheek tooth of Cuvieronius. Thus, there are no records of Stegomastodon in Central America (Lucas et al., 2007).

\section{Haplomastodon}

Among the South American gomphotheres, the taxonomy of Haplomastodon (Figs. 6-7) has been particularly problematic (e.g., Hoffstetter, 1950, 1952, 1955; Simpson and Paula Couto, 1957; ParodiBustos, 1962; Ficarrelli et al., 1993, 1995; Lucas et al., 1997; Lucas, 2008c, 2009a). Some workers regard it as a synonym of Stegomastodon (e.g., Alberdi et al., 2002; Prado et al., 2002, 2003, 2005), others treat it as a distinct genus (e.g., Ficarrelli et al., 1993, 1995; Lucas et al., 1997), whereas others regard it as a synonym of Notiomastiodon (Madden, 1984; Ferretti, 2008). We continue to regard Haplomastodon as a distinct taxon. The distinction between Haplomastodon and the very similar genus Cuvieronius is skull shape (relatively tall and short in Haplomastodon, low and long in Cuvieronius) and tusk morphology (upwardly curved and lacking enamel in adult Haplomastodon, not upwardly curved with spiral enamel bands in Cuvieronius) (Figs. 6-7). We distinguish Haplomastodon from Notiomastodon primarily by the more complex molar crowns of Notiomastodon (cf. Cabrera, 1929).

Only one record of Haplomastodon has been claimed in Central America--a subadult lower jaw, isolated molars and tusk fragment from Barra Honda in Costa Rica (Lucas \& Alvarado, 1991b; Lucas et al., 1997, fig. 7). Identification as Haplomastodon was based on the relatively straight tusk with a straight enamel

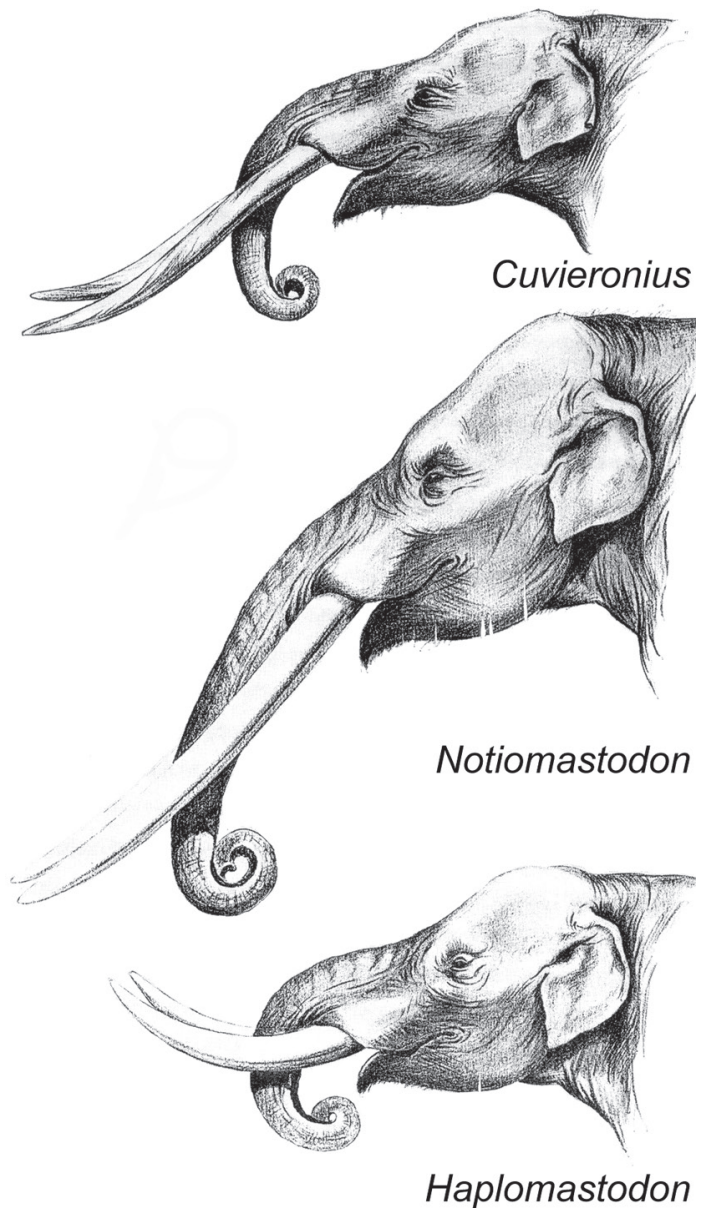

Fig. 7: Restorations of the heads of the three South American gomphotheres: Cuvieronius hyodon, Notiomastodon platensis and Haplomastodon waringi. Modified from Simpson \& Paula Couto (1957)

band, supposedly characteristic of juvenile Haplomastodon (Simpson \& Paula Couto, 1957). However, we now conclude that the tusk fragment of the Barra Honda gomphothere is too short (too incomplete) to document the curvature and enamel band morphology of the specimen, and, in the absence of more conclusive evidence, it is better identified as Cuvieronius hyodon (cf. Laurito, 1990). Thus, although Haplomastodon is very abundant in northern South America (i.e. Colombia), at the moment there are no definitive Central American records of Haplomastodon. 


\section{Mammuthus}

Mammoths (Mammuthus) (Fig. 2) are probably the best known fossil proboscideans. They have a fossil record in the Plio-Pleistocene of Eurasia and in the North American Pleistocene. Our perception of the evolution and taxonomy of North American Mammuthus is that of Maglio (1973), Agenbroad and co-workers (Agenbroad, 1984, 1994, 2005; Agenbroad \& Mead, 1996) and Lucas and collaborators (Lucas, 1996; Lucas \& Effinger, 1991; Lucas et al., 1993, 1999, 2000). Thus, Mammuthus immigrated into North America via Beringia at or near the beginning of the Irvingtonian LMA, 1.6-1.8 Ma. Indeed, its first appearance datum has traditionally been used to define the beginning of the Irvingtonian LMA (Bell et al., 2004). The founder population of North American Mammuthus is well represented by the lower jaw of $M$. meridionalis (= M. hayi) from Tijeras Arroyo, New Mexico (Lucas, 1996; Lucas \& Effinger, 1991; Lucas et al., 1993).

Polymorphic populations of North American Mammuthus evolved gradually through the Pleistocene, much as did Old World Mammuthus (Lister, 1996). M. imperator (the Imperial mammoth) is the descendant of M. meridionalis in North America, and it co-occurs with mammoths with the morphology of M. meridionalis (older samples) and M. columbi (younger samples). M. columbi (the Columbian mammoth), the descendant of M. imperator, was the common Late Pleistocene mammoth in North America (Maglio, 1973; Agenbroad, 1984, 2005). Chronologically, M. meridionalis in North America is restricted to the Early Pleistocene (about 1.8 to $1.2 \mathrm{Ma}$ ), M. imperator is late Early and Middle Pleistocene (about 1.2 Ma to 130,000 years old), and most $M$. columbi are Late Pleistocene (about 130,000 to 10,000 years old).

Most Mammuthus records in Central America are of $M$. columbi, and are from Honduras, El Salvador, Nicaragua and Costa Rica (Fig. 1, Table 1, Appendix; Laurito \& Aguilar, 2007). However, more primitive and older Mammuthus ( $M$. cf. $M$. hayi of Cisneros, 2008, which we identify as $M$. meridionalis) are known from El Salvador. Clearly,
Mammuthus immigrated from North America into Central America during the Early Pleistocene.

\section{Mammut}

The American mastodont (Mammut americanum) (Fig. 2) is one of the most widely distributed Pleistocene proboscideans in North America. Records range in age from Blancan to Rancholabrean and extend from Alaska to Florida and to Puebla in central Mexico (e.g., Kurtén \& Anderson, 1980; Shoshani, 1990; Saunders, 1996; Polaco et al., 2001; Green, 2002); the southernmost record of M. americanum is in Honduras (Lucas \& Alvarado, 1991a). Characteristic features of the American mastodont include a low and long skull with long and curved tusks, no lower tusks and last molars with 4 or 5 lophs/lophids and no cusps (pillars) in the valleys. The single record of the American mastodont from Central America is of a M3 from San Pedro Sula, Honduras (Lucas \& Alvarado, 1991a).

\section{CENTRAL AMERICAN PROBOSCIDEAN RECORDS}

Proboscidean fossils are known from all of the Central American countries except Belize (Fig. 1, Table 1, Appendix). In the Appendix to this article, we review all of these records and provide discussion of the taxonomy, age and reliability of the proboscidean records from Central America. Below, we present a brief synopsis based on the much more detailed information in the Appendix.

\section{Guatemala}

Well-documented Guatemalan proboscidean records are of Gomphotherium and Cuvieronius, and it is likely that the Guatemalan records of Gomphotherium are of the same age as the Honduran records from the Gracias Formation (early Hemphillian). Guatemalan 
Cuvieronius records are most likely Late Pleistocene, whereas a single undocumented mammoth record (mentioned by ArroyoCabrales et al., 2007, p. 18) is also likely of Late Pleistocene age.

\section{Honduras}

Honduras has the most extensive record of Miocene proboscidean fossils in Central America and a less extensive Pleistocene record. Gomphotherium fossils in the Gracias Formation are numerous, well dated as early Hemphillian, and provide what we regard as the oldest reliablydated proboscidean records in Central America. Other Honduran records are Pleistocene occurrences of Cuvieronius, Mammthus columbi (Fig. 8) and the single Central American record of Mammut.

\section{El Salvador}

El Salvador has an extensive fossil record of proboscideans assigned to Gomphotherium, Cuvieronius and Mammuthus. Particularly significant is the Chalatenango record of the co-occurrence of primitive Mammuthus with Cuvieronius, which is confidently assigned an Early Pleistocene (Irvingtonian) age. This is the best evidence that both of these proboscidean genera were in Central America during the Irvingtonian, though it seems likely that Cuvieronius dispersed into Central America as early as the late Blancan. Other well-dated Irvingtonian records of $C$. hyodon are from Barranca del Sisimico and Tomayate in El Salvador (see Appendix). The welldated Rancholabrean record of $C$. hyodon at El Hormiguero (see Appendix) helps also to establish the presence of Cuvieronius in Central America during the Rancholabrean.

\section{Nicaragua}

All fossil records of proboscideans from Nicaragua are of Cuvieronius hyodon (rare) and more common Mammuthus columbi and appear to be of Late Pleistocene age. Their greatest significance lies in the relative abundance of $M$. columbi, suggestive of the presence of grasslands/savannah in parts of Nicaragua during the Late Pleistocene.

\section{Costa Rica}

Costa Rica has an extensive proboscidean fossil record dominated by fossils of Cuvieronius hyodon. One of them, the Santa Ana (Oviedo) site is well dated because the ignimbrite deposits that bracket the alluvial-palustrine strata that yield $C$. hyodon are dated by ${ }^{40} \mathrm{Ar} /{ }^{39} \mathrm{Ar}$ to $\sim 0.32$ Ma (Pérez et al., 2006). The Cuvieronius found at Bajo Barrantes appear to be, by stratigraphic correlations, Upper Pliocene to Lower Pleistocene (see the Appendix). The southernmost record of Mammuthus (M. columbi) is from Hacienda El Silencio in central Costa Rica. Miocene records of Gomphotherium are from San Gerardo de Limoncito and Santa Rita (see Appendix).

\section{Panama}

Only two fossil records of proboscideans are known from Panama, both of Cuvieronius hyodon, and these are relatively young, circa 45,000 years old (see Appendix).

\section{CENTRAL AMERICA AS THE PROBOSCIDEAN PATHWAY}

We divide the history of Central American proboscideans into three immigrations: (1) ar- 


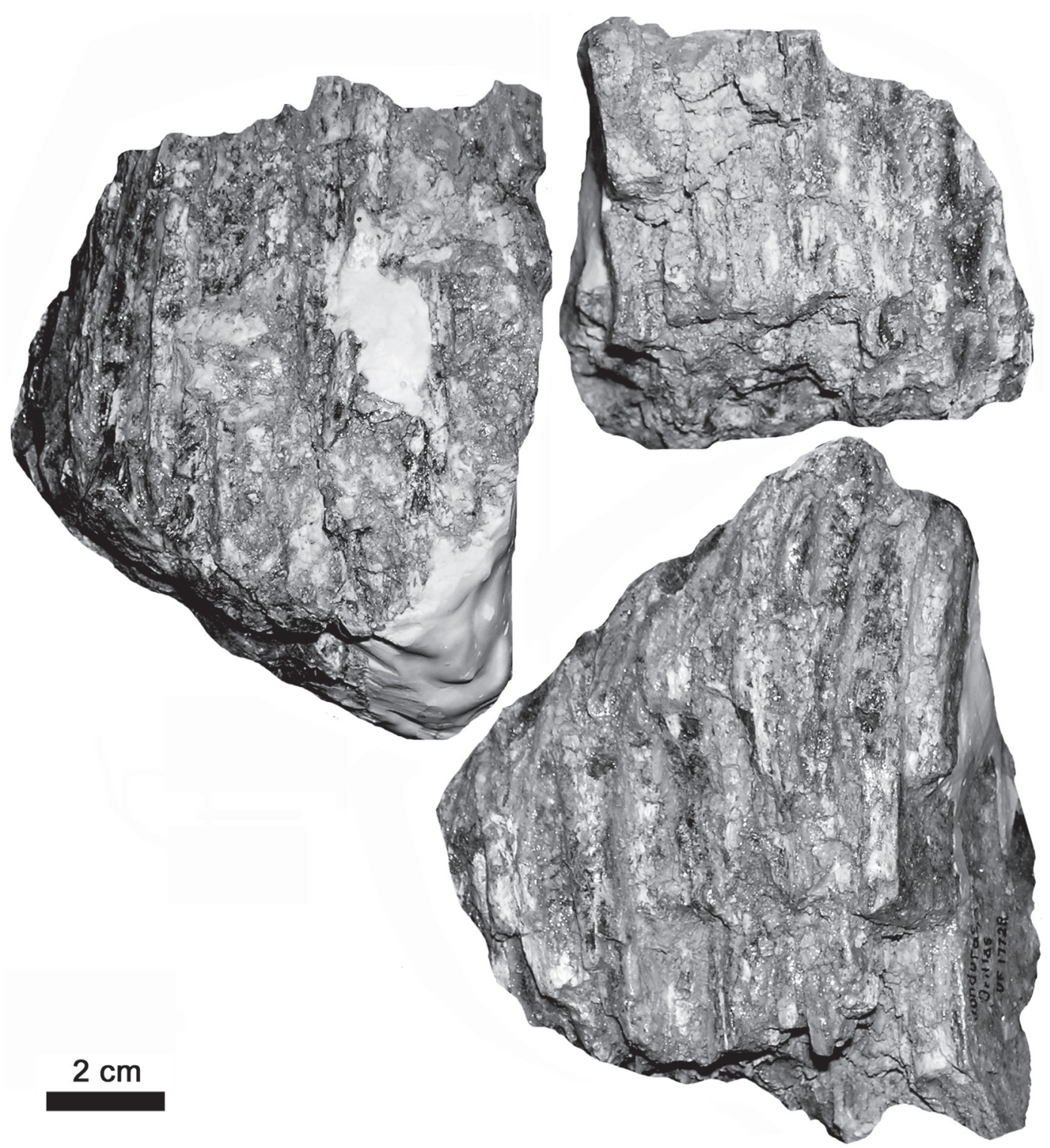

Fig. 8: Molar fragments of Mammuthus columbi from the Late Pleistocene Orillas del Humaya locality in Honduras. Fragments are catalogued as UF (Florida State Museum) 17728

rival of Gomphotherium during the Late Miocene (early Hemphillian); (2) arrival of Cuvieronius during the Pliocene (?) and Mammuthus during the Early Pleistocene (Irvingtonian); and (3) arrival of Mammut during the Late Pleistocene (Rancholabrean). We see no evidence for endemic 
evolution or a center of origin of proboscideans in Central America, as was most recently advocated by Woodburne et al. (2006), based largely on the supposed presence of Rhynchotherium in the Miocene of Honduras. Indeed, reassignment of the Honduran record of Rhynchotherium to Gomphotherium eliminates the only known evidence for the origin of a proboscidean taxon in Central America. All proboscidean genera known from Central America are also known from North America, which is where they apparently originated. Central America acted as a one way dispersal route for proboscideans from North America to Central America and, in one case, onward to South America (Fig. 9). We therefore refer to Central America as the "proboscidean pathway".

\section{Arrival of Gomphotherium}

The initial immigration of proboscideans into Central America apparently occurred during the Late Miocene (early Hemphillian), well documented and calibrated by the extensive record of Gomphotherium in the Gracias Formation of Honduras, and at the top of the Curré Formation in Costa Rica, the southernmost record of the genus. Gomphotherium records in El Salvador and Guatemala are also likely to be early Hemphillian records.

Prior to the Hemphillian, most of the Pacific slopes of Central America were covered by large shield ignimbritic volcanoes, yet North American mammals made it to Panama (Whitmore \& Stewart, 1965; MacFadden, 2006). Nevertheless, no proboscidean fossils are known from the preHemphillian Miocene (Barstovian) mammal assemblages of Panama (MacFadden, 2006). This suggests that proboscideans were confined to North America (including Mexico) for about nine million years, during the Middle and the earlyLate Miocene (Barstovian, Clarendonian and part of the Hemphillian), barred from tropical Central
America. The existence of large seaway barrier(s) between Mexico and Central America during the Miocene (cf. Alvarado et al., 2007) may have been a factor in restricting -- but not necessary impeding -- proboscidean immigration, though the Panamanian record of Miocene mammals indicates it was not an impenetrable barrier to the dispersal of North American mammals southward.

\section{Arrival of Cuvieronius and Mammuthus}

The oldest North American records of Cuvieronius are late Blancan, and the origin of the genus from Gomphotherium (or Rhynchotherium?) in North America was likely a late Blancan event (Lucas, 2008a). The co-occurrence of C. hyodon and a primitive Mammuthus (M. meridionalis) at Chaltenango in El Salvador is of Early Pleistocene (Irvingtonian) age, an age assignment indicated by similar co-occurrences in the southern United States (Lucas et al., 1999, 2000) and by the remainder of the Chaltenango fossil mammal assemblage (Cisneros, 2008). This is very significant because it indicates the presence of Cuvieronius and Mammuthus in Central America during the Early Pleistocene, though it is likely that Cuvieronius arrived earlier, in the Pliocene (Fig. 9). Cuvieronius evidently dispersed southward into South America soon after its arrival in Central America, because its oldest South American records are of Late Pliocene age (see below).

Mammuthus, however, never made it to South America (the only supposed South American records are very doubtful; see discussion and details in Alvarado, 1994 and Lucas et al., 2007). Thus, other than at Chaltanengo, its Central American records are of Mammuthus columbi and extend from El Salvador and western Honduras through Nicaragua into central Costa Rica. They are likely all of Late Pleistocene age, and reflect the maximum geographic distribution of that species. All 


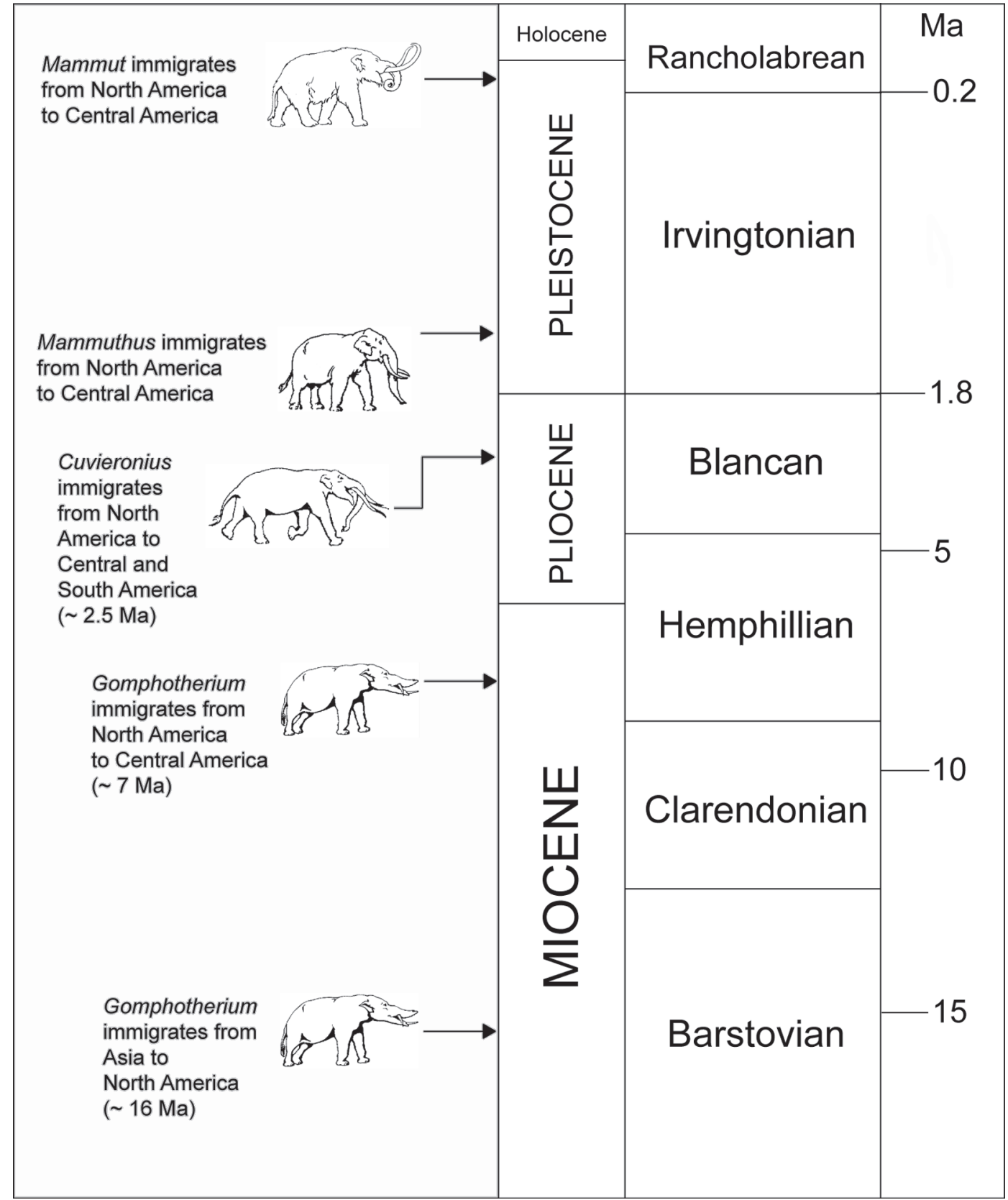

Fig. 9: Temporal distribution of key immigration events in the history of Central American Proboscidea 
mammoth fossil localities are on the Pacific slope of Central America. Mammoths were grazing proboscideans, and this suggests the presence of dry woodlands or thorn-scrub savannahs, probably reflecting the rain shadow created by regional uplift (i.e., Talamanca range) and the Central American volcanic range, which accompanied the closing of the Bolivar trench. The idea that by Late Pleistocene time all of Central America was rainforest (Raven \& Axelrod, 1975; Webb, 1991) is thus not well supported by the fossil distribution of Mammuthus, nor is it supported by the fossil record of Equus, Bison or by the vegetational history (Gómez, 1986). However, the absence of mammoths south of central Costa Rica is significant, indicating a barrier to their dispersal to the south-likely the tropical jungles of Panama and northern South America (the called "Darién plug"), which did not provide the vegetation necessary to the diet of mammoths (Prado et al., 2005). This barrier evidently also prevented Haplomastodon from entering Central America from northern South America.

\section{Arrival of Mammut}

Mammut, the American mastodont, has a single record in Central America from Honduras that lacks detailed provenance, so its precise age is uncertain. The maximum expansion of Mammut in North America was during the Late Pleistocene (Rancholabrean) (King \& Saunders, 1984; Saunders, 1996), so it seems likely that the Central American record reflects that expansion (Fig. 9). Although Mammut is confidently interpreted as a forest-living proboscidean that browsed on sylvan vegetation, it apparently did not disperse southward to South America, possibly because of a dietary specialization on a particular type of vegetation (Prado et al., 2005).

\section{Proboscidean extinction}

The Late Pleistocene extinction of proboscideans in Central America was part of the global extinction of the Late Pleistocene mammalian mega- fauna that is often attributed to overkill by human hunters or to climate change (warming) at the end of the last glacial age (e. g., Barnosky et al., 2004; Surovell et al., 2005; Koch \& Barnosky, 2006). Unfortunately, there are few reliable data to precisely date the youngest proboscidean fossil records in Central America, though no data support an age younger than Late Pleistocene (for example, in Costa Rica, the Cuvieronius record at Santa Ana is Middle Pleistocene, and the Cuvieronius from Paseo Colón and Tibás are much younger, apparently Late Pleistocene). Despite some claims to the contrary, there are currently no demonstrable human-proboscidean associations in Central America (Hurtado de Mendoza \& Alvarado, 1988; Lucas et al., 1997, 2008).

\section{IMPLICATIONS FOR PROBOSCIDEAN EVOLUTION IN SOUTH AMERICA}

There is no evidence that Central America acted as a center of evolution for proboscideans during the late Cenozoic. Instead, Central America was a pathway-another well trodden road across which the Proboscidea migrated to achieve a nearly global distribution during the Pleistocene. Gomphotherium arrived in Central America during the Late Miocene, Cuvieronius passed through during the Pliocene, Mammuthus arrived during the Early Pleistocene and Mammut arrived during the Late Pleistocene.

López et al. (2001) report proboscidean postcrania from the middle part of the Uquía Formation in northern Argentina, strata with a fission track age of $\sim 2.5 \mathrm{Ma}$ that have been correlated magnetostratigraphically to the upper part of the Gauss Chron (C2) (Reguero et al., 2007). This seems to us to be the most reliably dated, oldest record of proboscideans in South America, indicating their first appearance in the continent during the late Marplatan (Sanandresian) LMA (Alberdi \& Prado, 1995; Woodburne et al., 2006). Alberdi \& Prado (1995) have suggested that the oldest South American proboscidean records are of Cuvieronius hyodon, and, if correct, this indicates a rapid dispersal of Cuvieronius from North to South America very soon after the clo- 
sure of the Panamanian isthmus. The Central American record of this passage appears to be undiscovered because no Central American records of Cuvieronius are demonstrably Pliocene. The oldest reliably dated record of Cuvieronius in Central America is early Irvingtonian, though perhaps Blancan records exist, and we suggest that Cuvieronius passed through Central America during the Pliocene (Blancan), but we have not yet captured its presence until strata of early Irvingtonian age (Fig. 9).

Available data thus suggest a single immigration of Cuvieronius from Central America to South America during the Pliocene, and that this is the first entry of proboscideans into South America. Note that we agree with Alberdi et al. (2004) and Ferretti (2008) that "Amahuacatherium" from the "Miocene" of Peru (Campbell et al., 2000a, b, 2009, 2010) is a specimen of Haplomastodon most likely from a deposit of Late Pleistocene age. However, if Amahuacatherium is accepted as a distinct proboscidean taxon from a Miocene (older than 9.5 Ma) deposit, then it could be argued that the late Hemphillian ( $7 \mathrm{Ma})$ appearance of Gomphotherium in Central America postdates an earlier immigration of gomphotheres into South America. Nevertheless, there are no known South American gomphotheres between the putative age of Amahuacatherium $(<9.5$ $\mathrm{Ma})$ and their oldest reliably dated record $(\sim 2.5$ Ma). Proboscidean immigrations into Eurasia and into North America during the Miocene were followed rapidly by diversification and proliferation, so that proboscidean fossils became common components of post-immigration fossil assemblages. If Amahuacatherium demonstrates a Miocene immigration of proboscideans into South America, why are there no proboscidean fossils for at least seven million years? This is another argument against the Miocene age of Amahuacatherium. Instead, we believe that the South American fossil record of proboscideans begins in the Pliocene (Marplatan) and is followed by an abundance and diversity of proboscideans in the Pleistocene. This is consistent with the single Pliocene immigration of Cuvieronius into South America followed by diversification into
Haplomastodon and Notiomastodon, and a rapid spread of proboscideans to as far south as Chile and southern Argentina.

The absence of Stegomastodon in Central America does not support the immigration of this genus into South America advocated by Alberdi et al. $(2002,2004,2007)$ and Prado et al. (2003). Recognition of Notiomastodon as a distinct genus to encompass specimens from South America previously assigned to Stegomastodon (Cabrera, 1929; Madden, 1984; Ferretti, 2008) also does not support the concept of an immigration of Stegomastodon from North to South America. South American proboscideans are thus a modest Plio-Pleistocene evolutionary radiation of Cuvieronius hyodon in the Andean Cordillera and its apparent descendants Notiomastodon and Haplomastodon in the Brazilian tropical lowlands and the Argentine pampas.

\section{ACKNOWLEDGMENTS}

We benefited from the generosity of various collections managers and curators in North America and Central America for access to proboscidean fossils. We are also grateful to various colleagues who helped us in field and in different museums during more than 25 years of our research in Central America. Marco Ferretti, Marisol Montellano Ballesteros and Michael Pasenko provided helpful comments on this manuscript.

\section{REFERENCES}

ACUÑA-MESÉN，R. \& GARCÍA-DÍAZ，E., 1998: Nuevo ejemplar de Cuvieronius hyodon (Proboscidea: Gomphotheriidae) del Pleistoceno de Costa Rica.- Rev. Biol. Trop. 46: 1-9.

AGENBROAD, L.D., 1984: New World mammoth distribution.- En: MARTIN, P.S. \& KLEIN, R.G. (eds.): Quaternary extinctions.- Univ. of Arizona Press, Tucson, 90-108. 
AGENBROAD, L.D., 1994: Taxonomy of North American Mammuthus and biometrics of the Hot Springs mammoths.En: AGENBROAD, L.D. \& MEAD, J. I. (eds.): The Hot Springs mammoth site: Rapid City.- Fenske Printing, 158-207.

AGENBROAD, L.D., 2005: North American proboscideans: Mammoths: The state of knowledge, 2003.- Quat. Internat. 126128: 73-92.

AGENBROAD, L.D. \& MEAD, J.I., 1996: Distribution and paleoecology of central and western North American Mammuthus.En: SHOSHANI, J. \& TASSY, P. (eds.): The Proboscidea.- Oxford Univ. Press, Oxford, 280-288.

ALBERDI, M.T. \& CORONA-M., E., 2005: Revisión de los gonfoterios en el Cenozoico tardío de México.- Rev. Mex. Cien. Geol. 22: $246-260$.

ALBERDI, M.T. \& PRADO, J.L., 1995: Los mastodontes de América del Sur. -En: ALBERDI, M.T., LEONE, G. \& TONNI, E. (eds.), Evolución biológica y climática de la región Pampeana durante los últimos cinco millones de años: Madrid.- Mus. Nac. de Ciencias Naturales, 279-292.

ALBERDI, M.T., PRADO, J.L. \& CARTELLE, C., 2002: El registro de Stegomastodon (Mammalia, Gomphotheriidae) en el Pleistoceno superior de Brasil.- Rev. Españ. Paleontol. 17: 217-235.

ALBERDI, M.T., PRADO, J.L \& SALAS, R., 2004: The Pleistocene Gomphotheriidae (Proboscidea) from Peru.- Neues Jahrb. Geol. Paläont. Abhand. 231: 423-452.

ALBERDI, M.T., PRADO, J.L., ORTIZJAUREGUIZAR, E., POSADAS, P. \& DONATO, M. 2007: Historical biogeography of trilophodont gomphotheres (Mammalia, Proboscidea) reconstructed applying dispersion-vicariance analysis. Cuad. Mus. Geomin. Instit. Geol. Min. España, 8: 9-14.

ALFARO, A. 1911: Comprobaciones geológicas.Bol. Fomento, 1: 123-131.

ALVARADO, G.E. 1986: Hallazgos de megamamíferos fósiles de Costa Rica.- Rev. Geol. Amér. Central, 4: 1-46.

ALVARADO, G.E., 1994: Historia Natural Antigua.- 232 págs. Editorial Teconológica de Costa Rica, Cartago.

ALVARADO, G.E., DENGO, C., MARTENS, U., BUNDSCHUH, J., AGUILAR, T. \& BONIS, S., 2007: Stratigraphy and geologic history.- En: BUNDSCHUH, J. \& ALVARADO, G.E. (eds.): Central America: Geology, resources and hazards. Taylor \& Francis, London, 345-394.

ALVARADO, G.E., BARQUERO, R., TAYLOR, W., LÓPEZ, A., CERDAS, A. \& MURILLO, J., 2009: Geología de la hoja General, Costa Rica.- Rev. Geol. Amér. Central, 40: 99-109.

ARROYO-CABRALES, J., POLACO, O. J., LAURITO, C., JOHNSON, E., ALBERDI, M. T. \& VALERIO, A. L., 2007: The proboscideans (Mammalia) from Mesoamerica.- Quat. Internat. 169-170: $17-23$.

BARNOSKY, A.D., KOCH, P.L., FERANEC, R.S., WING, S.L. \& SHABEL, A. B., 2004: Assessing the causes of late Pleistocene extinctions on the continents.Science, 300: 70-75.

BELL, C.J., LUNDELIUS, E.L., JR., BARNOSKY, A.D., GRAHAM, R.W., LINDSAY, E.H., RUEZ, D.R. JR., SEMKEN, H.A. JR., WEBB, S.D. \& ZAKRZEWSKI, R.J., 2004: The Blancan, Irvingtonian, and Rancholabrean mammal ages.- 
En: WOODBURNE, M.O. (ed.): Late Cretaceous and Cenozoic mammals of North America. Columbia University Press, New York, 232-314.

BOULE, M.\& THEVENIN,A., 1920: Mammifères fossiles de Tarija.- 256 págs, Soudier, París.

CABRERA, A., 1929: Una revisión de los mastodontes Argentinos.- Rev. Mus. La Plata, 32: 61-144.

CAMPBELL, K.E. Jr., FRAILEY, C.D. \& ROMERO-PITTMAN, L. , 2000a: The late Miocene gomphothere Amahuacatherium peruvium (Proboscidea: Gomphotheriidae) from Amazonian Peru: Implications for the great American faunal interchange.- Rep. Perú Sect. Energ. Minas Instit. Geol.. Min. Metal Bol. 23: 1-152.

CAMPBELL, K.E. Jr., HEIZLER, M., FRAILEY, C.D., ROMERO-PITTMAN, L. \& PROTHERO, D.R., 2000b: Upper Cenozoic chronostratigraphy of the southwestern Amazon basin.- Geol. 29: 595598.

CAMPBELL, K.E. Jr., FRAILEY, C.D. \& ROMERO-PITTMAN, L., 2009: In defense of Amahuacatherium (Proboscidea: Gomphotheriidae).- Neues Jahrb. Geol. Paläont. Abhand. 252: 113-128.

CAMPBELL, K.E. Jr., PROTHERO, D.R., ROMERO-PITTMAN, L., HERTEL, F. \& RIVERA, N. 2010: Amazonian magnetostratigraphy: Dating the first pulse of the Great American Faunal Interchange.- J. South. Amer. Earth Sci. 29:619-626.

CISNEROS, J.C., 2005: New Pleistocene vertebrate fauna from El Salvador.- Rev. Brasil. Paleont. 8: 239-255.

CISNEROS, J.C., 2008: The fossil mammals of El Salvador.- New Mex. Mus. Nat. Hist. Sci. Bull. 44: 375-380.
COPE, E.D., 1884: The extinct Mammalia of the Valley of Mexico.- Proc. Amer. Phil. Soc., 22: 1-21.

DALQUEST, W.W. \& SCHULTZ, G.E., 1992: Ice age mammals of northwestern Texas.309 págs. Midwestern State University Press, Wichita Falls.

DUDLEY, J.P., 1996: Mammoths, gomphotheres, and the great American faunal interchange.- En: SHOSHANI, J. \& TASSY, P. (eds.): The Proboscidea. Oxford University Press, Oxford, 289-295.

ESPINOZA, J., 1976: Evaluaciones arqueológicas en "El Bosque".- Inst. Geog. Nac. Managua, Minist. Obras Pub. 1: 22-45.

FERRETTI, M.P., 2008: A review of South American proboscideans.- New Mex. Mus. Nat. Hist. Sci. Bull. 44: 381-391.

FERRUSQUIA-VILLAFRANCA, I., 1984: A review of early and middle Miocene Tertiary faunas of North America.- J. Vert. Paleont. 4: 187-198.

FERRUSQUIA-VILLAFRANCA， I. 1990: Biostratigraphy of the Mexican continental Miocene; Part I, Introduction and the northwestern and central faunas; Part II, the southeastern (Oaxacan) faunas and concluding remarks on the discussed vertebrate record.- Univ. Nac. Autón. Méx. Instit. Geol. Paleont. Mex. 56: 7-109.

FICCARELLI, G., BORSELLI, V., MORENO ESPINOSA, M. \& TORRE, D., 1993: New Haplomastodon finds from the late Pleistocene of northern Ecuador.- Geobios, 26: 231-240.

FICCARELLI, G., BORSELLI, V., HERRERA, G., MORENO ESPINOSA, M. \& TORRE, D., 1995: Taxonomic remarks on the South American mastodons referred to Haplomastodon and Cuvieronius.Geobios, 28: 745-756. 
FISCHER DE WALDHEIM, G., 1814: Zoognosia, Tabulis synopticis illustrat. 3: 1-694.

FRASSINETTI, D. \& ALBERDI, T., 2000: Revisión y estudio de los restos fósiles de mastodontes de Chile (Gomphotheriidae): Cuvieronius hyodon, Pleistoceno superior.Est. Geol. 56: 197-208.

FRICK, C., 1933: New remains of trilophodonttetrabelodont mastodons.- Bull. Amer. Mus. Nat. Hist. 59: 505-652.

GAZIN, C.L., 1957: Exploration for remains of giant ground sloths in Panama.- Smithson. Rep. 1956: 341-354.

GHEERBRANT, E., 2009: Paleocene emergence of elephant relatives and the rapid radiation of African ungulates.- Proc. Nat. Acad. Sci. USA, 106: 10717-10721.

GÓMEZ, L.D., 1986: Vegetación de Costa Rica.327 págs. EUNED, San José.

GREEN, J.L., 2002: Mammut americanum (Kerr, 1792).- Fossil Spec. Florida, 1: 1-11.

GUTIÉRREZ, F., 1963: Hallazgos de restos de un mamut.- Inst. Geogr. Nac. Costa Rica Inf. Semest. 3: 41-47.

GUZMÁN, D., 1950: Paleontología Nacional: De cómo llegaron a El Salvador los animales antediluvianos. -An. Mus. Nacion. El Salv. 1: 75-77.

HECKERT, A.B., LUCAS, S.G. \& MORGAN, G.S., 2000: Specimens of Gomphotherium in the New Mexico Museum of Natural History and Science and the specieslevel taxonomy of North American Gomphotherium.- New Mex. Mus. Nat. Hist. Sci. Bull. 16: 187-194.

HIBBARD, C.W. \& DALQUEST, W.W., 1966: Fossils from the Seymour Formation of Knox and Baylor Counties, Texas, and their bearing on the late Kansan climate of the region.- Contrib. Mus. Paleont. Univ. Michigan, 21(1): 1-66.

HOFFSTETTER, R., 1950: Observaciones sobre los mastodontes de Sud América y especialmente del Ecuador. Haplomastodon subgen. nov. de Stegomastodon.- Public. Esc. Politéc. Nac. 1: 1-39.

HOFFSTETTER, R., 1952: Les mammifères Pléistocènes de la République de L'Équateur.- Mém. Soc. Géol. France, Nouv. Sér. 31: 1-391.

HOFFSTETTER, R., 1955: Remarques sur la classification et la phylogénie des mastodontes sud-américains.- Bull. Mus. Nat. d'Hist. Natur. 27: 484-491.

HULBERT, R.C. JR. (ed.), 2001: The fossil vertebrates of Florida.- 350 págs. University Press of Florida, Gainesville.

HURTADO DE MENDOZA, L. \& ALVARADO, G.E., 1988: Los mastodontes en el Nuevo Mundo y el problema de su taxonomía: Una perspectiva arqueológica para América Central.- Tecnol. Marcha, 9: 61-76.

IBARRA, J.A., 1980: Paleontología en Guatemala.- 52 págs. Ed. José de Pineda Ibarra, Ciudad de Guatemala.

JIMÉNEZ, T.F., 1959: Noticias sobre un mastodonte del Canton San Juan Buenavista.Cultura, 13: 205-220.

KING, J.E. \& SAUNDERS, J.J., 1984: Environmental insularity and extinction of the American mastodont.- En: MARTIN, P.S. \& KLEIN, R.G. (eds): Quaternary extinctions.- University of Arizona Press, 315-339.

KOCH, P.L. \& BARNOSKY, A.D., 2006: Late Quaternary extinctions: State of the debate.Ann. Rev. Ecol. Evol. Syst. 37: 215-250. 
KURTÉN, B. \& ANDERSON, E., 1980: The Pleistocene mammals of North America.442 págs. Columbia Univ. Press, New York.

LAMBERT, W.D., 1996: The biogeography of the gomphotheriid proboscideans of North America.- En: SHOSHANI, J. \& TASSY, P. (eds): The Proboscidea: Evolution and palaeoecology of elephants and their relatives.- Oxford Univ. Press, 143-148.

LAMBERT, D.W. \& SHOSHANI, J., 1998: Proboscidea. -En: JANIS, C., SCOTT, K. \& JACOBS, L.L. (eds): Evolution of Tertiary mammals of North America. Volume 1. Terrestrial carnivores, ungulates and ungulate-like mammals.- Cambridge University Press, 606-621.

LARDÉ, J., 1924: Geología general de Centro América y especial de El Salvador.- 82 págs. Imprenta Nacional, San Salvador.

LARDÉ, J., 1950: La región fosilífera de San Juan del Sur; informe científico del Profesor Don Jorge Larde al Ministerio de Instrucción Pública.- An. Mus. Nac. El Salv. 1: 78-88.

LARDÉ-Y-LARÍN, J., 1950: Índice provisional de las regiones fosilíferas de El Salvador.Anal. Mu. Nac. El Salv. 1: 69-74.

LAURITO, C.A., 1988: Los proboscídeos fósiles de Costa Rica y su contexto en la América Central.- Vínculos, 14: 29-58.

LAURITO, C.A., 1990: Estudio de un ejemplar de Cuvieronius hyodon hallado en el lecho del Rio Nacaome, Guanacaste, Costa Rica. - Rev. Geol. Amér. Central, 11: 41-50.

LAURITO, C. \& AGUILAR, D.H., 2007: El registro de Mammuthus (Proboscidea, Elephantidae) en la República de El Salvador, América Central.- Rev. Geol. Amér. Central, 34: 73-81.
LAURITO, C.A. \& VALERIO, A.L., 2004: Nuevo registro de Cuvieronius? para el Pleistoceno de Costa Rica.- Brenesia, 62: 77-82.

LAURITO, C.A. \& VALERIO, A.L., 2005: First record of Rhynchotherium blicki (Frick, 1933) for the late Cenozoic of Costa Rica.Rev. Geol. Amér. Central, 33: 75-82.

LAURITO, C.A. \& VALERIO, A.L., 2008a: Ictiofauna de la localidad de San Gerardo de Limoncito, Formación Curré, Mioceno Superior, Cantón de Coto Brus, Provincia de Puntarenas, Costa Rica.- Rev. Geol. Amér. Central, 39: 65-85.

LAURITO, C.A. \& VALERIO, A.L., 2008b: The first record of Gavialosuchus americanus Sellards (1915) † (Eusuchia: Crocodylidae, Tomistominae) for the Late Tertiary of Costa Rica and Central America.- Rev. Geol. Amér. Central, 39: 107-115.

LAURITO, C.A., VALERIO, W. \& VEGA, E., 1993: Nuevos hallazgos paleovertebradológicos en la Península de Nicoya: Implicaciones paleoambientales y culturales de la fauna de Nacaome.- Rev. Geol. Amér. Central, 16: 113-115.

LECONTE, J., 1858: On a mastodon bed in Honduras.- Proc. Acad. Nat. Sci. Phila, 10: 7.

LEIDY, J., 1859: [On a mastodon tooth from Honduras].- Proc. Acad. Nat. Sci. Phila, 11: 91 .

LEIDY, J., 1869: The extinct mammalian fauna of Dakota and Nebraska, including an account of some allied forms from other localities, together with a synopsis of the mammalian remains of North America.- J. Acad. Nat. Sci. Phila. 7: 1-472.

LEIDY, J., 1886: Toxodon and other remains from Nicaragua.- Proc. Acad. Nat. Sci. Phila. 275-277. 
LISTER, A.M., 1996: Evolution and taxonomy of Eurasian mammoths.- En: SHOSHANI, J. \& TASSY, P. (eds): The Proboscidea: Evolution and palaeoecology of elephants and their relatives.- Oxford Univ. Press, 203-213.

LÓPEZ, G., REGUERO, M. \& LIZUAIN, A., 2001: El registro más antiguo de mastodontes (Plioceno tardío) de América del Sur.- Ameghin. 38 (suppl.): 35R-36R.

LUCAS, S.G., 1996: The Thornton Beach mammoth: Consistency of numerical age and morphology.- Quarter. Res. 45: 332-333.

LUCAS, S.G., 2003: Pleistocene proboscideans from Lago de Chapala, Jalisco, Mexico.Curr. Res. Pleisto. 20: 105-107.

LUCAS, S.G., 2005: New information on the Pleistocene mammals from Nicaragua.Curr. Res. Pleisto. v. 21, p. 97-99.

LUCAS, S.G., 2008a: Cuvieronius (Mammalia, Proboscidea) from the Neogene of Florida.- New Mex. Mus. Nat. Hist. Sci. Bull. 44: 31-38.

LUCAS, S.G., 2008b: Pleistocene mammals from Yeroconte, Honduras.- New Mex. Mus. Nat. Hist. Sci. Bull. 44: 403-407.

LUCAS, S.G., 2008c: Taxonomic nomenclature of Cuvieronius and Haplomastodon, proboscideans from the Plio-Pleistocene of the New World.- New Mex. Mus. Nat. Hist. Sci. Bull. 44: 409-415.

LUCAS, S.G., 2009a: Case 3480 Mastodon waringi Holland, 1920 (currently Haplomastodon waringi; Mammalia, Proboscidea): Proposed conservation of usage by designation of a neotype.- Bull. Zool. Nomen. 66: 164-167.
LUCAS, S.G., 2009b: Case 3479 Cuvieronius Osborn, 1923 (Mammalia, Proboscidea): Proposed conservation.- Bull. Zool. Nomen. 66: 1-6.

LUCAS, S.G. \& ALVARADO, G.E., 1991a: El hallazgo más austral de un Mammut americanum: El caso del mastodonte de San Pedro Sula, Honduras.- Rev. Geol. Amér. Central, 13: 85-89.

LUCAS, S.G. \& ALVARADO, G.E., 1991b: Comentario sobre la clasificación del mastodonte de Barra Honda (Río Nacaome), Guanacaste, Costa Rica.- Rev. Geol. Amér. Central, 13: 97-98.

LUCAS, S.G. \& ALVARADO, G.E., 1995: El proboscideo Rhynchotherium blicki (Mioceno Tardío) del oriente de Guatemala.- Rev. Geol. Amér. Central, 18: 19-24.

LUCAS, S.G. \& EFFINGER, J.A., 1991: Mammuthus from Lincoln County and a review of the mammoths from the Pleistocene of New Mexico.- New Mex. Geol. Soc. Guideb. 42: 277-282.

LUCAS, S.G. \& MORGAN, G.S., 2005: Ice age proboscideans of New Mexico.- New Mex. Mus. Nat. Hist. Sci. Bull. 28: 255-261.

LUCAS, S.G. \& MORGAN, G.S., 2008: Taxonomy of Rhynchotherium (Mammalia, Proboscidea) from the Miocene-Pliocene of North America.- New Mex. Mus. Nat. Hist. Sci. Bull. 44: 71-87.

LUCAS, S.G., ALVARADO, G.E. \& VEGA, E., 1997: The Pleistocene mammals of Costa Rica.- J. Vert. Paleont. 17: 413-427.

LUCAS, S. G., MORGAN, G. S. \& ESTEP, J. W., 2000: Biochronological significance of the co-occurrence of the proboscide- 
ans Cuvieronius, Stegomastodon, and Mammuthus in the lower Pleistocene of southern New Mexico.- New Mex. Mus. Nat. Hist. Sci. Bull. 16: 209-216.

LUCAS, S.G., WILLIAMSON, T.E. \& SOBUS, J., 1993: Plio-Pleistocene stratigraphy, paleoecology, and mammalian biochronology, Tijeras Arroyo, Albuquerque area, New Mexico.- New Mex. Geol. 15: 1-8.

LUCAS, S.G., MORGAN, G.S. ESTEP, J. W., MACK, G.H. \& HAWLEY, J.W., 1999: Co-occurrence of the proboscideans Cuvieronius, Stegomastodon, and Mammuthus in the lower Pleistocene of southern New Mexico.- J. Vert. Paleont. 19: 595-597.

LUCAS, S.G., GARCIA, R., ESPINOZA, E., ALVARADO, G.E., HURTADO DE MENDOZA, L. \& VEGA, E., 2008: The fossil mammals of Nicaragua.- New Mex. Mus. Nat. Hist. Sci. Bull. 44:417-429

LUCAS, S.G., ALVARADO, G.E., GARCIA, R., ESPINOZA, E., CISNEROS, J.C. \& MARTENS, U., 2007: Vertebrate paleontology.- En: BUNDSCHUH, J. \& ALVARADO, G.E. (eds): Central America: Geology, resources and hazards.- Taylor \& Francis, 443-451.

MACFADDEN, B.J., 2006: North American Miocene land mammals from Panama.- J. Vert. Paleont. 26: 720-734.

MADDEN, C.T., 1984: The Proboscidea of South America.- Geol. Soc. Amer. Abstr. Progr. 12: 474.

MADDEN, C.T. \& MOTA-VIDAURRE, B., 1989: First appearance of proboscideans in New World: Two Old World species -Zygolophodon tapiroides and
Gomphotherium angustidens- from earlier middle Miocene of Guatemala.- Geol. Soc. Amer. Abs. Progr. 21: A116.

MAGLIO, V.J., 1973: Origin and evolution of the Elephantidae.- Trans. Amer. Phil. Soc., New Series, 63: 1-149.

MCGREW, P.O., 1942: Field Museum paleontological expedition to Honduras.- Science, 96: 85.

MELÉNDEZ, C., 1954: Vertebrados fósiles de Costa Rica.- Bol. Mus. Nac. Costa Rica, 3: 9-14.

MILLER, W.E., 1990: A Rhynchotherium skull and mandible from southeastern Arizona.BYU Geol. Stud. 36: 57-67.

MONTELLANO-BALLESTEROS， M., 2002: New Cuvieronius finds from the Pleistocene of central Mexico.- J. Paleont. 76: 578-583.

MORA, S., 1981: Barra Honda.- 96 págs. Univ. Estatal a Distancia, San José.

MOTA-VIDAURRE, B., 1989: Stratigraphy of the coal-bearing strata (Miocene) in the Carboneras region, Izabal, Guatemala.- 83 págs. Colorado School of Mines, Golden [Tesis M.Sc.].

NORDENSKIÖLD, E., 1903: Über die Saugetierfossilien des Tarijatals, Südamerika. I. Mastodon andium Cuv.- Kun. Sven. Veten. Akad. Hand. 37: 1-30.

OLSON, E.C. \& MCGREW, P.O., 1941: Mammalian fauna from the Pliocene of Honduras.- Geol. Soc. Amer. Bull. 52: 1219-1244

OSBORN, H.F. 1926: Additional new genera and species of the mastodontoid Proboscidea.Amer. Mus. Novit., 238: 1-16. 
OSBORN, H.F., 1936: Proboscidea Volume I: Moeritheroidea Deinotheroidea Mastodontoidea.- 802 págs. The Amer. Mus. Press, New York.

PARODI, R., 1962: Los mastodontes sudamericanos y su clasificación.- Univ. Nac. Tucumán, Facultad Cienc. Nat. Cuad., 2: 1-41.

PEARSON, G.A. 2005: Late Pleistocene megafaunal deposits of the Isthmus of Panama and their paleoenvironmental implications.- Carrib. J. Sci. 41: 1-13.

PÉREZ, W., ALVARADO, G.E. \& GANS, P.B., 2006: The 322 ka Tiribí Tuff: Stratigraphy, geochronology and mechanism of deposition of the largest and most recent ignimbrite in the Valle Central, Costa Rica.- Bull. Volcanol. 69: 25-40.

POLACO, O.J., ARROYO-CABRALES, J., CORONA-M., E. \& LÓPEZ-OLIVA, J.G., 2001: The American mastodon Mammut americanum in Mexico.- En: CAVARRETTA, G., GIOIA, P., MUSSI, M. \& PALOMBO, M.R. (eds): La terra degli Elefanti. Atti del 1o Congresso Internazzionale.- Consiglio Nazuionale delle Ricerche, 237-242.

POMPECKJ, J.F. 1905: Mastodon-Reste aus dem interandien Hochland von Bolivia.Palaeontograph. 52: 17-56.

PRADO, J.L., ALBERDI, M.T. \& GÓMEZ, G., 2002: Late Pleistocene gomphotheres (Proboscidea) from the Arroyo Tapalque locality (Buenos Aires, Argentina) and their taxonomic and biogeographic implications.- Neues Jahr. Geol. Paläont., Abhand. 225: 275-296.

PRADO, J.L., ALBERDI, M.T., SANCHEZ, B. \& ARANZA, B. 2003: Diversity of the Pleistocene gomphotheres (Gomphotheriidae, Proboscidea) from South America.- Deinsea, 9: 347-363.
PRADO, J.L., ALBERDI, M.T., AZANZA, B., SANCHEZ, B. \& FRASSINETTI, D. 2005: The Pleistocene Gomphotheriidae (Proboscidea) from South America.- Quat. Internat. 126-128: 21-30.

PROTHERO, D.R., DAVIS, E.B. \& HOPKINS, S.S.B. 2008: Magnetic stratigraphy of the Massacre Lake Beds (late Hemingfordian, Miocene), northwest Nevada, and the age of the "proboscidean datum" in North America.- New Mex. Mus. Nat. Hist. Sci. Bull. 44: 239-246.

RAVEN, P. H. \& AXELROD, D.I., 1975: History of the flora and fauna of Latin America.Am. Sci. 63:420-429.

REGUERO, M.A., CANDELA, A.M. \& ALONSO, R.N., 2007: Biochronology and biostratigraphy of the Uquia Formation (Pliocene-early Pleistocene, NW Argentina) and its significance in the great American biotic interchange.- J. South Amer. Earth Sci. 23: 1-16.

RESHETOV, V.J., 1982: Reporte preliminar sobre la observación de la paleontología de Nicaragua.-13 págs. Acad. of Sci. USSR [Unpublished Report, Spanish translation].

SAPPER, K., 1905: Gebirgsbau und Boden des südlichen Mittlelamerika.- 82 págs. Justus Perthes en Gotha, Nr. 151.

SAUNDERS, J.J., 1996: North American Mammutidae.-En: SHOSHANI, J. \& TASSY, P. (eds): The Proboscidea: Evolution and palaeoecology of elephants and their relatives.- Oxford Univ. Press, 271-279.

SEGURA, A., 1938: Apuntes sobre el curso de geología para divulgación científica.- Rev. Agricul. 5: 501-509.

SEGURA, A., 1942: Sección de geología: informe rendido a la Secretaría de Educación 
Pública sobre la labor realizada en 1940.Ser. Hist. Mus. Nac. 1: 15-20.

SHOSHANI, J. 1990: Distribution of Mammut americanum in the New World.- Curr. Res. Pleist. 7: 124-126.

SHOSHANI, J. \& TASSY, P., 1996: Summary, conclusions, and a glimpse into the future.En: SHOSHANI, J. \& TASSY, P. (eds): The Proboscidea: Evolution and palaeoecology of elephants and their relatives.Oxford Univ. Press, 335-348.

SHOSHANI, J., WEST, R.M., COURT, N., SAVAGE, R.J.G. \& HARRIS, J.M., 1996: The earliest proboscideans: General plan, taxonomy, and palaeoecology.- En: SHOSHANI, J. \& TASSY, P. (eds): The Proboscidea.- Oxford Univ. Press, 57-75.

SIMPSON, G.G. \& PAULA COUTO, C. 1957: The mastodons of Brazil.- Bull. Amer. Mus. Nat. Hist. 112: 125-190.

SNARSKIS, M.J., GAMBOA, H. \& FONSECA, O., 1977: El mastodonte de Tibás, Costa Rica.- Vínculos, 3: 1-3.

SQUIER, E.G., 1859: A visit to the Guajiquero Indians.- Harpers' New Month. Mag. 19 (113): 602-619.

STIRTON, R.A. \& GEALEY, W.K., 1949: Reconnaissance geology and vertebrate paleontology of El Salvador, Central America.- Geol. Soc. Amer. Bull. 60: 1731-1754.

SUROVELL, T., WAGUESPACK, N. \& BRANTINGHAM, P.J., 2005: Global archaeological evidence for proboscidean overkill.- Proc. Nat. Acad. Sci. USA, 102: 6231-6236.

TASSY, P. 1996: The earliest gomphotheres. -En: SHOSHANI, J. \& TASSY, P. (eds): The Proboscidea: Evolution and palaeoecology of elephants and their relatives.- Oxford Univ. Press, 89-91.

TEDFORD, R.H., ALBRIGHT, L.B. III, BARNOSKY, A.D., FERRUSQUIAVILLAFRANCA, I., HUNT, R.M. JR., STORER, J.E., SWISHER, C.C. III, VOORHIES, M.R., WEBB, S.D. \& WHISTLER, D.P., 2004: Mammalian biochronology of the Arikareean through Hemphillian interval (late Oligocene through early Pliocene epochs).- En: WOODBURNE, M.O. (ed.): Late Cretaceous and Cenozoic mammals of North America.- Columbia Univ. Press, 169-231.

TOBIEN, H., 1973: On the evolution of mastodonts (Proboscidea, Mammalia). Part 1: The bunodont trilophodont groups.- Hess. Landes. Boden. Wies. 101: 202-276.

TOBIEN, H., 1978 : On the evolution of the mastodonts (Proboscidea, Mammalia), Part 2 : The bunodont tetralophodont groups.Geol. Jahrb. Hessen, 106 :159-208.

VALERIO, A.L. \& LAURITO, C.A., 2008 : Dental remains of immature individuals of Rhynchotherium blicki (Frick 1933) of San Gerardo de Limoncito, Coto Brus, Costa Rica.- Rev. Geol. Amér. Central, 39: 87-91.

VANCE, T., 2002: A review of the Pleistocene proboscideans of Texas (exclusive of the mammoths).- Occas. Pap. Dallas Paleont. Soc. 5: 155-201.

VINSON, G.L., 1962: Upper Cretaceous and Tertiary stratigraphy of Guatemala.- Amer. Assoc. Petrol. Geol. Bull. 46: 425-456.

WEBB, S.D., 1991: Ecogeography and the great American interchange.- Paleobiol. 17: 266-280.

WEBB, S.D. \& PERRIGO, S.C., 1984: Late Cenozoic vertebrates from Honduras and El Salvador.- J. Vert. Paleo. 4: 237-254. 
WEBB, S.D. \& PERRIGO, S.C., 1985: New megalonychid sloths from El Salvador.- En: MONTGOMERY, G. (ed.): The evolution and ecology of armadillos, sloths, and vermilinguas.- Smithson. Inst. Press, 113-120.

WEBB, S. D. \& TESSMAN, N., 1968: A Pliocene vertebrate fauna from low elevation in Manatee County, Florida.- Amer. J. Sci. 266: 777-811.

WHITMORE, F. C. JR. \& STEWART, R. H., 1965: Miocene mammals and Central American seaways. -Science, 148: 180-185.

WOODBURNE, M.O., 1961: Upper Pliocene geology and vertebrate paleontology of part of the Meade basin, Kansas.- Pap. Mich. Acad. Sci., Arts, and Letters, 46: 61-101.

WOODBURNE, M.O., 1969: A late Pleistocene occurrence of the collared peccary, Dicotyles tajacu, in Guatemala.- J. Mammal., 50: 121-125.

WOODBURNE, M.O., CIONE, A.L., \& TONNI, E. P., 2006: Central American provincialism and the great American biotic interchange.- En: CARRANZA-CASTANEDA, Ó. \& LINDSAY, E.H. (eds): Advances in late Tertiary vertebrate paleontology in Mexico and the great American biotic interchange.Univ. Nac. Autónoma de Méx., Inst. de Geol. y Centro de Geocienc., Pub. Esp. 4: 73-101. 


\section{APPENDIX}

Proboscidean fossils are known from all of the Central American countries except Belize (Fig. 1, Table 1). In this Appendix, we review all of these records and provide discussion of the taxonomy, age and reliability of the proboscidean records from Central America. We do so by first discussing proboscidean records that we consider reliable - those based on fossil specimens that have been described (illustrated), or on fossils that we have examined or that have been reported by a reliable authority. Then, we also list less reliable records, which are numerous and often little more than reports without any documentation.

\section{Guatemala}

Chinautla: Osborn (1926, p. 12; also see Osborn 1936, p. 432) named the new species Serridentinus guatemalensis for an incomplete upper molar from Chinautla, but provided no more detailed provenance. This tooth clearly belongs to Gomphotherium (Lucas et al., 2007), and $S$. guatemalensis is likely a synonym of $G$. hondurensis. This is presumably a Miocene record.

Estanzuela: a tooth of Mammuthus columbi collected by Barnum Brown (we have seen this molar in the Museo Estanzuela in Zacapa) together with other Late Pleistocene mammal fossils.

Río Carboneras: Lucas \& Alvarado (1995) reported isolated cheek teeth they assigned to "Rhynchotherium blicki" from the Herreria Formation along the Río Carboneras in eastern Guatemala (also see Mota-Vidaurre, 1989; Madden \& Mota-Vidaurre, 1989). Based on this record, they suggested a Hemphillian age by correlation to the Gracias Formation in Honduras. We concur and consider this a likely Hemphillian record of Gomphotherium hondurensis (cf. Lucas \& Morgan, 2008).

Río de la Pasión: Woodburne (1969) reported Cuvieronious? as part of an extensive Late Pleistocene (Rancholabrean) mammal assemblage from a playa of the Río de la Pasión near the town of Santa Amelia.
Río Usumancita: Vinson (1962) mentioned the presence of Cuvieronius in Pleistocene deposits in the vicinity of the Río Usumancita in the Petén-Chiapas frontier.

Zacapa: In the Museo Estanzuela in Zacapa we have examined molars and a mounted skeleton of Cuvieronius hyodon found in the vicinity of Zacapa. These are presumably Pleistocene fossils.

Other localities: Ibarra (1980) lists several proboscidean records from Guatemala that lack documentation: (1) Jutiapa- " "pieza de mamut:" (2) Huehuetenango - a mastodont; (3) Chinautla-Cuvieronius or "Haplomastodon;" and (4) Tulumaje y Tulumajillo-a proboscidean.

\section{Honduras}

Gracias Formation: Various localities in the Gracias Formation, between Gracias and Las Flores in western Honduras, yield an extensive assemblage of Late Miocene (early Hemphillian) vertebrate fossils including the type material and other specimens previously assigned to Aybelodon hondurensis and Blickotherium blicki (Frick, 1933; Olson \& McGrew, 1941; Webb \& Perrigo, 1984; Lucas \& Morgan, 2008) (Fig. $3)$. Assigning these proboscidean fossils to one taxon is well accepted (Webb \& Tessman, 1968; Tobien, 1973; Webb \& Perrigo, 1984; Lucas \& Morgan, 2008), and they were long placed in the genus Rhynchotherium. However, revision of the genus excludes these species, which are regarded as derived specimens of Gomphotherium (Lucas \& Morgan, 2008). This is a significant taxonomic conclusion because it eliminates the oldest supposed record of Rhynchotherium (North American records begin during the latest Hemphillian) and eliminates the principal Rhynchotherium record in Central America.

Orillas del Humaya: The cutbank of the Rio Humaya, north of Comayagua, yields a Late Pleistocene vertebrate fossil assemblage that includes two broken molars of Mammuthus. Webb \& Perrigo (1984, p. 252) report a plate frequency of $8 / 100 \mathrm{~mm}$ and identified the fossils as Mammuthus 
cf. M. columbi. These molars are in the Florida State Museum catalogued as UFL 17728 (Fig. 8). Their relatively thin plates and thin enamel bands justify assignment to $M$. columbi.

San Pedro Sula: Lucas \& Alvarado (1991a) documented a right M3 of the American mastodont, Mammut americanum, from San Pedro Sula in northern Honduras. Nothing is known about the geological provenance of this fossil, and we assume it is of Rancholabrean age.

Tambla: Leidy (1859) reported an isolated molar collected from Tambla (= present day Humaya: M. Bonta, written commun, 2010) that he identified as Mastodon, and later illustrated (Leidy, 1869, pl. 27, fig. 14) and referred to it as possibly belonging to "Mastodon andium". Osborn (1936, fig. 454C) also illustrated this tooth (it is a left M3), and we have examined it in the collection of the Academy of Natural Sciences in Philadelphia. Osborn (1936) assigned the Tambla molar to Rhynchotherium, but it is indistinguishable from Cuvieronious hyodon, to which we assign it (as did Lucas et al., 2007, fig. 16.2.a). Earlier, LeConte (1858, p. 7) mentioned the "Mastodon bed" near "Tambla", assigning the fossils to "Mastodon giganteus". Squier (1859, p. 610) also noted that "huesos grandes" are present "about a league from Tambla, in a sandstone formation, and consist of a large deposit of the fossilized bones of the mastodon....not simply the remains of a single skeleton, but of several...." Squier (1859, p. 610) also illustrated a molar in a dentary fragment from this bone bed that appears to us to be $C$. hyodon.

Yeroconte: The Yeroconte locality in northwestern Honduras yields a Late Pleistocene (Rancholabrean) vertebrate fossil assemblage dominated by remains of the giant ground sloth Eremotherium laurillardi. It includes the isolated humerus and ulna of a gomphothere, probably (but not demonstrably) Cuvieronius (McGrew, 1942; Webb \& Perrigo, 1984; Lucas, 2008b, fig. 6).

Other localities: (1) Tamara-Sapper (1905, p. 12-13) reported bones of a "mastodont" from near Tamara as follows: “Según el Dr. Fritzgärtner, en el camino de Tegucigalpa a Támara afloran primero margas, areniscas y conglomerados y luego tobas blancas. Debajo de las tobas se descubrieron cerca de Támara, maderas petrificadas y carneolos rojos así como también algunos huesos de mastodonte...." (2) Potrerillo--Sapper (1905, p. 12-13) also reported a mastodont skeleton "Cerca de Potrerillo, en el departamento de Paraíso, afloran rocas calcáreas, en Danlí en parte conglomerados de cuarzo y en parte sedimentos cuaternarios. El Dr. Fritzgärtner encontró en el cuaternario de Danlí, un esqueleto casi completo de mastodonte, el cual fue llevado al Museo Nacional de Tegucigalpa, que ahora no existe."

\section{El Salvador}

Barranca del Sisimico: Cuvieronius sp. has been reported from this locality, which is along the Río Sisimico, approximately $1.5 \mathrm{~km} \mathrm{SW}$ of the $67 \mathrm{~km}$ mark on the Pan American Highway. The site is in the Cuscatlán Formation (Webb \& Perrigo, 1984), and is considered to be Early Pleistocene (Irvingtonian) based on the primitive evolutionary stage of the two ground sloth species collected there (Webb \& Perrigo, 1985).

Cantón Magdalena: Cisneros (2008) reported an indeterminate gomphotheriid from Caserío la Criva (Municipality of Chalchuapa).

Chalatenango: Cisneros (2008) documented Mammuthus and Cuvieronius specimens from the Department of Chalatenango. He assigned a partial left lower molar to Mammuthus cf. M. hayi, and a partial tusk to Cuvieronius. Based on the tentative identification of Mammuthus $\mathrm{cf}$. M. hayi, he assigned the site an Irvingtonian age. We regard this as a primitive Mammuthus best assigned to $M$. meridionalis following the taxonomy of Maglio (1973) and Lucas et al. (1993, 1999, 2000). This new find of Mammuthus is remarkable for its co-occurrence with Cuvieronius, similar to several co-occurrences of these genera in the United States (Hibbard \& Dalquest, 1966; Webb \& Dudley, 1995; Lucas et al., 1999, 2000). These North American localities are of Irvingtonian age, which suggests Mammuthus meridionalis (=M. hayi) was the only mammoth species to co-exist with Cuvieronius. Webb \& Dudley (1995) suggested that M. meridionalis and Cuvieronius formed mixed herds in coastal savannas. 
Corinto: A series of exposures of alluvial sediments between ignimbrite units in the Río Torola Valley (Municipality of Corinto) yielded a Hemphillian mammal assemblage including "Rhynchotherium blicki" (Cisneros, 2008), which we assign to Gomphotherium hondurensis (cf. Lucas \& Morgan, 2008). The Corinto mammal assemblage is correlated to the Hemphillian Gracias Formation assemblage in Honduras (Webb \& Perrigo, 1984). Cisneros (2008) also correlated Corinto with the Río Carboneras site in eastern Guatemala (Herrería Formation) based on the specimens of "Rhynchotherium blicki" reported by Lucas \& Alvarado (1995).

Río de Jerusalén: A molar of Mammuthus "jeffersonii" (Stirton \& Gealey, 1949; Lardé-yLarín, 1950), which we attribute to M. columbi.

San Juan del Sur (El Hormiguero): This long known locality (Stirton \& Gealey, 1949; Lardé, 1950; Webb \& Perrigo, 1984) is on San Juan del Sur farm, between the departments of Morazán and San Miguel, and yields a Rancholabrean-age mammal assemblage (Bison is present) that includes Cuvieronius hyodon.

Santa Ana: A complete mandible, incorrectly referred to Titanotherium (Lardé-y-Larín, 1950), is most likely a proboscidean (Cisneros, 2008); also, Laurito (1988) reported two Cuvieronius hyodon molars from Santa Ana.

Tomayate: This site, along the Río Tomayate (Apopa Municipality), is considered to be Irvingtonian by Cisneros $(2005,2008)$. In addition to other mammals, there is a large concentration of the proboscidean Cuvieronius hyodon within a stratum of unconsolidated ash. Assigning an Irvingtonian age to the locality is based mainly on the presence of the glyptodont Glyptotherium arizonae and the camel Hemiauchenia cf. H. seymourensis.

Other localities: Less reliable proboscidean localities in El Salvador were reported by Lardé (1924, 1950) and Lardé y Larín (1950): (1) Acahuapa-Lempaa (proboscidean maxillary fragment: Lardé-y-Larín, 1950); (2) Gruta de Corinto (proboscidean molar: Lardé, 1924; Lardé, 1950; Lardé-y-Larín, 1950); (3) Chalchuapa (proboscidean molar: Lardé, 1924; Lardé-yLarín, 1950); (4) Colinas de Jucuarán (probably a proboscidean skeleton, including an incomplete tusk, vertebrae and fragments of femora: Lardéy-Larín, 1950); (5) El Almendro (proboscidean mandibular ramus with molars: Lardé-y-Larín, 1950); (6) Ilobasco (proboscidean molars and unidentified fragmented bones: Guzmán, 1950; Lardé-y-Larín, 1950); (7) Jayaque (proboscidean molars and other bones: Lardé, 1924; Lardéy-Larín, 1950); (8) Nueva Esparta (two proboscidean molars: Lardé-y-Larín, 1950); (9) Río Chula - in the stream bed of the Río Chula (a proboscidean molar and other fragmented bones: Stirton \& Gealey, 1949); (10) Río de Los Frailes (a rather complete proboscidean skeleton: Guzmán, 1950); this find is unusual due to the mention of a lower mandible with a small tusk, which suggests it may belong to a sub-adult individual of Mammut americanum (adults do not have tusks) or to a non-Pleistocene gomphotheriid (Gomphotherium); (11) San Agustín (incomplete upper proboscidean tusk and other associated bones: Lardé-y-Larín, 1950); and (12) San Juan Buenavista (several remains of a proboscidean, partially articulated: Jiménez, 1959); photographs of an incomplete molar (Jiménez, 1959: p. 12) suggest Cuvieronius.

\section{Nicaragua}

El Bosque: At the El Bosque locality, southwest of Pueblo Nuevo, Espinoza (1976) reported (but did not document) Stegomastodon and Gomphotherium. Reshetov (1982) pointed out that this record should be revised, and Laurito \& Valerio (2005) said that such a preliminary determination was never confirmed and the specimen(s) could correspond to Cuvieronius. In fact, these identifications are highly unlikely given the Late Pleistocene age of the El Bosque fossil assemblage (Lucas et al., 2008). At El Bosque, only the presence of the proboscidean Cuvieronius hyodon can be verified based on an incomplete molar (Lucas et al., 2008).

El Palmar: Lucas et al. (2008) documented the partial skeleton of a mammoth (including a lower jaw) collected from volcaniclastic sands at the El Palmar (Las Moras) locality in southern Nicaragua, which is north of the highway 
between Rivas and Tola in the drainage of the Río Chacalapa. The partial mammoth skeleton from El Palmar consists of the lower jaw, the glenoid portions of both scapulae, both humeral heads, the proximal ends of both ulnae, several vertebral centra, many rib fragments, some carpals and an incomplete femur. The lower jaw contains the left and right $\mathrm{m} 3 \mathrm{~s}$. Morphology and metrics of the jaw and teeth are characteristic of Mammuthus columbi (Lucas, 2005; Lucas et al., 2008).

Jalapa: The Jalapa (El Chorro) locality is in a channel deposit of a Pleistocene river on the northeast bank of the small river called El Chorro, southwest of Jalapa, in northernmost Nicaragua (Lucas et al., 2008). Leidy (1886) first reported fossil mammals from Nicaragua at Jalapa, including "Mastodon andium". Some of the fossils Leidy described are still housed in the Academy of Natural Sciences, Philadelphia (Lucas et al., 2008), but we have not been able to locate the fossils that Leidy identified as "Mastodon andium", which most likely would be referred to Cuvieronius hyodon (Lucas, 2008a, c).

Las Banderas: Lucas et al. (2008) mentioned the presence of mammoth postcranial bones in alluvium at a stone quarry near Las Banderas in northern Nicaragua.

Masachapa: Lucas et al. (2008) documented molar and tusk fragments of Mammuthus columbi from the Masachapa locality. The locality is an alluvial deposit that forms a sea cliff near Masachapa in southwestern Nicaragua.

Matagalpa: At Matagalpa, numerous bones and a molar of the proboscidean Cuvieronius were collected from the bank of the Rio Viejo. These fossils are documented in a photograph taken 27 February 1940 by Omas Medrano and stored in the Museo Nacional de Nicaragua archive, but the fossils are apparently lost, and we have not relocated the fossil site (Lucas et al., 2008).

Other localities: Two less reliable records of proboscidean fossils are known from Nicaragua: (1) Jinotepe-Lucas et al. (2008) noted that south of Lake Aranás (north of Jinotepe), some proboscidean postcrania were discovered while digging a water well but were subsequently lost; and (2) Sébaco-Lucas et al. (2008) reported bones of a mammoth (now lost) from the Sébaco (Palo Verde) locality, which is a man-made well dug just west of the Río Grande de Matagalpa.

\section{Costa Rica}

Lucas et al. (1997) provided a detailed review of the fossil proboscidean record in Costa Rica, so we mostly present a synopsis based on their report.

Agua Caliente: Left M2 and dentary fragment with m2-3 of Cuvieronius hyodon (Laurito, 1988; Lucas et al., 1997).

Bajo Barrantes: A neural spine, probably of Cuvieronius (Lucas et al., 1997).

Buenos Aires de Palmares: Alvarado (1986) described the locality; Laurito (1988) and Lucas et al. (1997) assigned molars, a jaw fragment and a scapula to Cuvieronius hyodon.

Cachí: Cuvieronius hyodon (Laurito, 1988).

Candelaria (Quebrada Grande de Palmares): Cuvieronius hyodon (Laurito, 1988).

Claras de Guayabo de Mora: Left and right m3s of Cuvieronius hyodon (Alvarado, 1986; Laurito, 1988; Lucas et al., 1997).

Hacienda del Silencio: Incomplete lower molar of Mammuthus columbi (Gutiérrez, 1963; Lucas et al., 1997, fig. 8)

Península de Nicoya: Five localities (Hacienda las Ánimas, Nicoya, Quirimán, Barra Honda and San Fernando) yield proboscidean fossils from surficial alluvium, colluvium and/or swamp sediments (Alvarado, 1986: Lucas et al., 1997). From Hacienda las Ánimas, Alfaro (1911) and Segura (1938, 1942) reported "Mammut andium" "from Hacienda las Animas", and Laurito (1988, figs. 25-27) and Lucas et al. (1997) documented a right $\mathrm{m} 2$ of Cuvieronius hyodon. From the Nicoya 2 locality, Segura (1942) originally reported Trilophodon sp., but Lucas et 
al. (1997) later documented molar fragments of C. hyodon. Lucas et al. (1997) also documented a $\mathrm{m} 3$ fragment of $C$. hyodon from the Nicoya 1 locality. Segura $(1938,1942)$ and Meléndez (1954) reported Mastodon sp. from Quirimán de Nicoya. At Barra Honda (Río Nacaome), $C$. hyodon is known from a left $\mathrm{p} 4$, incomplete right m3 and incomplete molar (Mora, 1981; Laurito, 1990; Lucas et al., 1997; Acuña-Mesén \& GarcíaDíaz, 1998), and from a lower jaw (Laurito et al., 1993). At San Fernando, vertebrae have been referred tentatively to Cuvieronius (Lucas et al., 1997).

Tibás 1: Tip of tusk, molar fragments and distal end of femur of Cuvieronius hyodon (Snarskis et al., 1977; Laurito, 1988; Lucas et al., 1997).

Tibás 2: Tusk and molars of Cuvieronius hyodon (Laurito, 1988; Lucas et al., 1997).

Quebrada Rivera (Tibás 3): Molar of Cuvieronius hyodon (Laurito \& Valerio, 2004).

Río María Aguilar: Right $\mathrm{m} 2$ of Cuvieronius hyodon (Laurito, 1988; Lucas et al., 1997).

Paseo Colón: Incomplete molars of Cuvieronius hyodon (Alvarado, 1986; Laurito, 1988; Lucas et al., 1997).

Santa Ana (Sitio Oviedo): Tusk fragments and a right $\mathrm{m} 3$ of Cuvieronius hyodon (Alvarado, 1986; Laurito, 1988; Lucas et al., 1997).

Santo Domingo: Molar fragments of Cuvieronius hyodon (Alvarado, 1986; Laurito, 1988; Lucas et al., 1997).

San Gerardo de Limoncito: Valerio \& Laurito (2008) documented two decidouous premolars and tusk fragments with enamel bands that they assigned to "Rhynchotherium" (=Gomphotherium) blicki. However, the deciduous premolars and tusk fragments are not easily distinguished from Cuvieronius hyodon (compare, especially, Valerio \& Laurito, 2008, fig. 1 with Lucas, 2008a, fig.6A). Particularly significant is the relatively broad anterior lophids of the Costa Rican deciduous premolars, which apparently distinguish them from the deciduous premolars of Gomphotherium, which have relatively narrow anterior lophids so that the teeth have a more triangular occlusal outline than do the Costa Rican deciduous premolars (compare Valerio \& Laurito, 2008, fig. 1 to Frick, 1933, figs. 33, 37). Thus, is necessary to emphasize and clarify that there is an overlapping range of morphological variation in deciduous teeth of Gomphotherium and Cuvieronius.

The selachians (sharks and rays), such as Isurus desori, Isogomphodon caunellensis, and Hemipristis serra, from San Gerardo de Limoncito are Miocene taxa (Laurito \& Valerio, 2008a). Other vertebrate and invertebrate fossils from San Gerardo de Limoncito have a longer chronological range (Oligocene to Pliocene), and the microforaminiferan Orbulina universa (Laurito \& Valerio, 2008a, b) is present and has a temporal range from Middle Miocene to Holocene. Thus, the concurrent range zone age of the fossiliferous layer is Middle to Late Miocene. An inferred and more restricted age assignment of Late Miocene (Hemphillian) can be advocated because the fan delta deposits that contain the fossil layer are located at the top of the Curré Formation (Valerio $\&$ Laurito, 2008), also in agreement with regional stratigraphic correlations (i.e. Alvarado et al., 2009). An Early Pliocene age is more speculative. Therefore, based on its biostratigraphic position (Miocene, perhaps Upper Miocene), the proboscidean from San Gerardo de Limoncito is more likely Gomphotherium. We thus identify this as a Miocene record of Gomphotherium in Table 1.

Santa Rita: Laurito and Valerio (2005) identified a palate with M2-3s as "Rhynchotherium" blicki, with an estimated age of Early Pliocene, but later evaluation confirms that the fossiliferous conglomerate corresponds to the same conglomerate of the locality of San Gerardo de Limoncito, previously described (located $9.8 \mathrm{~km}$ to the west of Santa Rita), and therefore it is of probable Late Miocene age (Valerio \& Laurito, 2008). But as noted by Lucas $\&$ Morgan (2008), this specimen lacks diagnostic features of Rhynchotherium, and based on its age is best identified as Gomphotherium. 
Other localities: Lucas et al. (1997, table 1) listed various additional proboscidean records from Costa Rica that cannot be further documented: Quirimán de Nicoya, Nicoya 1, Nicoya 2, San Fernando, Quebrada Fierro, Cirri de Naranjo, San Miguel de Turrúcares, and Potrero Grande.

\section{Panama}

El Hatillo: On the Azuero Peninsula, Gazin (1957, p. 347) identified Cuvieronius associated with other Late Pleistocene mammals, including Equus, Eremotherium and Glossotherium.

La Trinidaíta: Also on the Azuero Peninsula, this locality is about $9 \mathrm{~km}$ west of Pesé. Pearson (2005) reported Cuvieronius tropicus (tooth fragments, vertebrae, part of a rib and a tiba) associated with Eremotherium. He obtained radiocarbon ages of $\sim 45,00014 \mathrm{C}$ yr. B. P. on charcoal associated with the bones. Pearson (2005) also inferred that this is a likely age for Gazin's nearby El Hatillo locality, which is to say that the Panamanian Cuvieronius records (which we assign to $C$. hyodon) date from the Marine Isotope Stage 3 interstadial. 